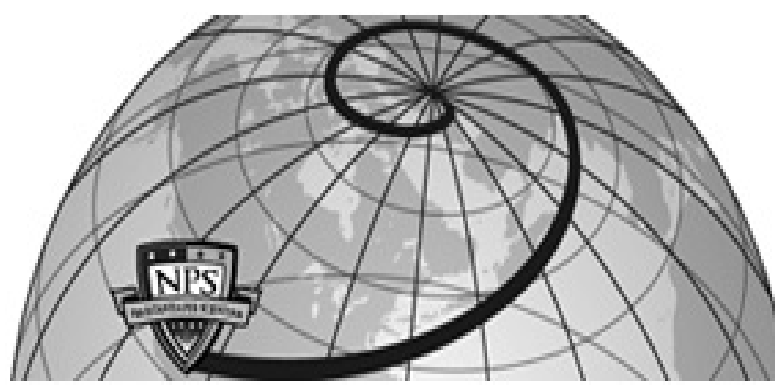

Calhoun: The NPS Institutional Archive DSpace Repository

An analysis of factors affecting the retention plans of junior male U.S. Army officers : evidence from the 1999 DOD survey of active duty personnel

Gencer, Umit.

Monterey, Calif. Naval Postgraduate School

http://hdl.handle.net/10945/6061

Copyright is reserved by the copyright owner

Downloaded from NPS Archive: Calhoun

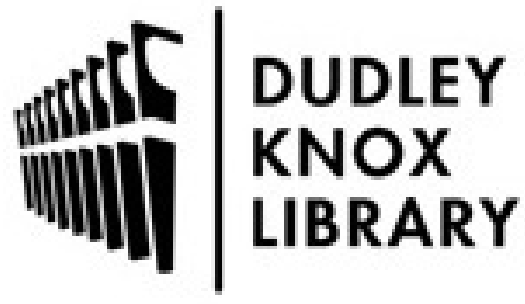

http://www.nps.edu/library
Calhoun is the Naval Postgraduate School's public access digital repository for research materials and institutional publications created by the NPS community. Calhoun is named for Professor of Mathematics Guy K. Calhoun, NPS's first appointed -- and published -- scholarly author.

Dudley Knox Library / Naval Postgraduate School 411 Dyer Road / 1 University Circle Monterey, California USA 93943 


\section{NAVAL POSTGRADUATE SCHOOL Monterey, California}

\section{THESIS}

\begin{tabular}{|} 
AN ANALYSIS OF FACTORS AFFECTING THE \\
RETENTION PLANS OF JUNIOR MALE U.S. ARMY \\
OFFICERS: EVIDENCE FROM THE 1999 DOD SURVEY \\
OF ACTIVE DUTY PERSONNEL \\
by \\
Umit Gencer \\
March 2002 \\
Thesis Co-Advisors: & George W. Thomas \\
& Kathryn Kocher \\
\hline
\end{tabular}

Approved for public release; distribution is unlimited 

Public reporting burden for this collection of information is estimated to average 1 hour per response, including the time for reviewing instruction, searching existing data sources, gathering and maintaining the data needed, and completing and reviewing the collection of information. Send comments regarding this burden estimate or any other aspect of this collection of information, including suggestions for reducing this burden, to Washington headquarters Services, Directorate for Information Operations and Reports, 1215 Jefferson Davis Highway, Suite 1204, Arlington, VA 22202-4302, and to the Office of Management and Budget, Paperwork Reduction Project (0704-0188) Washington DC 20503.

\begin{tabular}{|l|c|c|}
\hline 1. AGENCY USE ONLY (Leave blank) & $\begin{array}{c}\text { 2. REPORT DATE } \\
\text { March } 2002\end{array}$ & $\begin{array}{c}\text { 3. REPORT TYPE AND DATES COVERED } \\
\text { Master's Thesis }\end{array}$
\end{tabular}

4. TITLE AND SUBTITLE: AN ANALYSIS OF FACTORS AFFECTING THE 5 . FUNDING NUMBERS

RETENTION PLANS OF JUNIOR MALE US ARMY OFFICERS: EVIDENCE FROM THE 1999 DOD SURVEY OF ACTIVE DUTY PERSONNEL

6. AUTHOR(S) Gencer, Umit

7. PERFORMING ORGANIZATION NAME(S) AND ADDRESS(ES)

Naval Postgraduate School

Monterey, CA 93943-5000

8. PERFORMING

ORGANIZATION REPORT NUMBER

9. SPONSORING / MONITORING AGENCY NAME(S) AND ADDRESS(ES)

N/A

10. SPONSORING / MONITORING AGENCY REPORT NUMBER

11. SUPPLEMENTARY NOTES The views expressed in this thesis are those of the author and do not reflect the official policy or position of the Department of Defense or the U.S. Government.

\begin{tabular}{l|l} 
12a. DISTRIBUTION / AVAILABILITY STATEMENT & 12b. DISTRIBUTION CODE
\end{tabular}

Approved for public release; distribution is unlimited.

\section{ABSTRACT (maximum 200 words)}

This thesis investigates the factors that influence the retention intentions of 680 junior male Army officers who are serving within their initial obligated service. To estimate the models, data for this thesis were drawn from responses to the 1999 DoD Survey of Active Duty Personnel. The survey includes data on retention intentions of service members. Past research has shown that a member's intention is a good predictor of retention behavior. Logistic regression analysis is used to identify demographic, tenure, economic, and cognitive characteristics that significantly affect the intention to stay or to quit the military and to assess their relative importance. The SAS software package is used to analyze the data.

The model developed for this thesis is successful in identifying several factors influencing the retention intentions of junior male Army officers. Eight of the seventeen variables included in the model have a significant impact upon retention. Officers' decision to remain on active duty were significantly influenced by the demographic characteristics of family status and race; the tenure characteristics of military rank $(\mathrm{O} 3)$ and military life expectation; the economic characteristics of the probability of finding a good civilian job, and the cognitive characteristics of satisfaction with military intrinsic values, military career advancement opportunities, and military deployment and economic life.

A quadrant analysis of the satisfaction variables is used to indicate areas for improvement in order to raise the military's overall level of job satisfaction. High impact candidate areas for improvement were identified: workload, personal time, and enjoyment satisfaction. These are excellent candidates for immediate attention since they have a considerable impact on overall satisfaction with military life and have substantial room for improvement.

Finally, this thesis recommends areas for further related research and future policy.

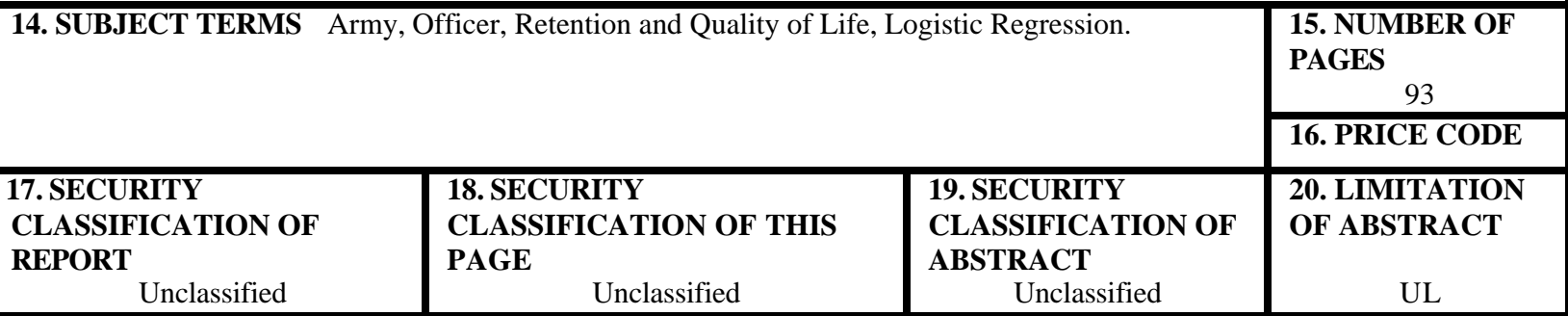

NSN 7540-01-280-5500

Standard Form 298 (Rev. 2-89)

Prescribed by ANSI Std. 239-18 
THIS PAGE INTENTIONALLY LEFT BLANK 
Approved for public release; distribution is unlimited

\title{
AN ANALYSIS OF FACTORS AFFECTING THE RETENTION PLANS OF JUNIOR MALE US ARMY OFFICERS: EVIDENCE FROM THE 1999 DOD SURVEY OF ACTIVE DUTY PERSONNEL
}

\author{
Umit Gencer \\ First Lieutenant, Turkish Army \\ B.S., Turkish Military Academy, 1997 \\ Submitted in partial fulfillment of the \\ requirements for the degree of \\ MASTER OF SCIENCE IN MANAGEMENT
}

from the

NAVAL POSTGRADUATE SCHOOL

March 2002

Author: $\quad$ Umit Gencer

Approved by: $\quad$ George W. Thomas, Thesis Co-Advisor

Kathryn Kocher, Thesis Co-Advisor

Doug Brook, Dean, Graduate School of Business and Public Policy 
THIS PAGE INTENTIONALLY LEFT BLANK 


\begin{abstract}
This thesis investigates the factors that influence the retention intentions of 680 junior male Army officers who are serving within their initial obligated service. To estimate the models, data for this thesis were drawn from responses to the $1999 \mathrm{DoD}$ Survey of Active Duty Personnel. The survey includes data on retention intentions of service members. Past research has shown that a member's intention is a good predictor of retention behavior. Logistic regression analysis is used to identify demographic, tenure, economic, and cognitive characteristics that significantly affect the intention to stay or to quit the military and to assess their relative importance. The SAS software package is used to analyze the data.

The model developed for this thesis is successful in identifying several factors influencing the retention intentions of junior male Army officers. Eight of the seventeen variables included in the model have a significant impact upon retention. Officers' decision to remain on active duty were significantly influenced by the demographic characteristics of family status and race; the tenure characteristics of military rank $(\mathrm{O} 3)$ and military life expectation; the economic characteristics of the probability of finding a good civilian job, and the cognitive characteristics of satisfaction with military intrinsic values, military career advancement opportunities, and military deployment and economic life.

A quadrant analysis of the satisfaction variables is used to indicate areas for improvement in order to raise the military's overall level of job satisfaction. High impact candidate areas for improvement were identified: workload, personal time, and enjoyment satisfaction. These are excellent candidates for immediate attention since they have a considerable impact on overall satisfaction with military life and have substantial room for improvement.
\end{abstract}

Finally, this thesis recommends areas for further related research and future policy. 
THIS PAGE INTENTIONALLY LEFT BLANK 


\section{TABLE OF CONTENTS}

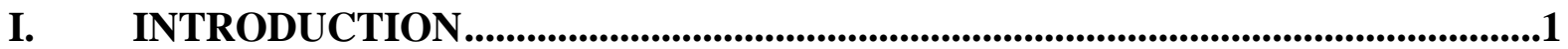

A. BACKGROUND ..............................................................................................

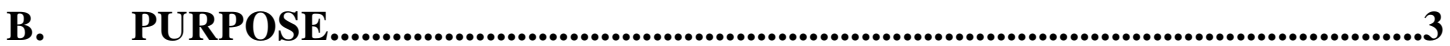

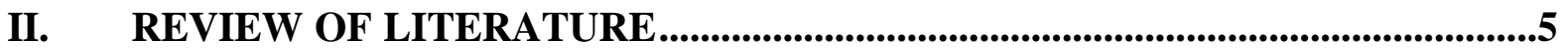

A. REENLISTMENT INTENTION AND ACTUAL BEHAVIOR ...................5

B. TURNOVER THEORY ..................................................................................8

C. MILITARY TURNOVER RESEARCH........................................................12

III. MODEL DEVELOPMENT ................................................................................21

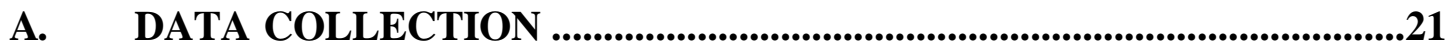

B. SURVEY DESCRIPTION ................................................................................21

C. MODEL DATA DESCRIPTION .....................................................................23

D. HYPOTHESIZED RETENTION MODEL …...............................................29

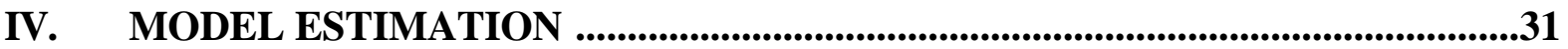

A. DEPENDENT VARIABLE AND MODEL SPECIFICATION ..................31

B. EXPLANATORY VARIABLE DEFINITIONS AND HYPOTHESIZED RELATIONSHIPS ........................................................33

C. MODEL RESULTS ..........................................................................................40

D. GOODNESS OF FIT .........................................................................44

V. QUADRANT ANALYSIS .........................................................................................

VI. CONCLUSIONS AND RECOMMENDATIONS.................................................51

A. CONCLUSIONS AND RECOMMENDATIONS...........................................51

B. FUTURE RESEARCH..................................................................................53

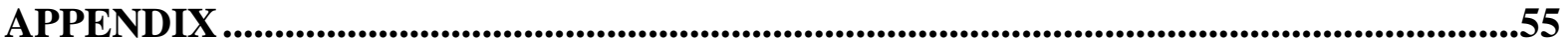

LIST OF REFERENCES ....................................................................................................73

INITIAL DISTRIBUTION LIST .......................................................................................................77 
THIS PAGE INTENTIONALLY LEFT BLANK

viii 


\section{LIST OF FIGURES}

Figure 1. Mobley and et al. Turnover Model, "After [Ref.16]"...................................12

Figure 2. $\quad$ The Hypothesized Retention Model ......................................................29

Figure 3. Comparison of Binomial Logit Model and Linear Probability Model,

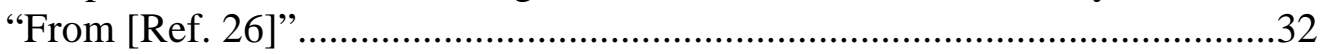

Figure 4. Quadrant Analysis for Junior Army Male Officers .....................................49 
THIS PAGE INTENTIONALLY LEFT BLANK 


\section{LIST OF TABLES}

Table 1. A Summary of Major Findings in Turnover Research ................................17

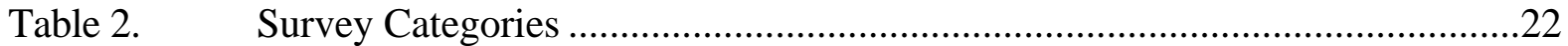

Table 3. Gender and Branch of Service ..................................................................2

Table 4. Company-Grade Officers Pay Grade Distribution.........................................23

Table 5. Male Junior Officers Pay Grade Distribution for Thesis Analysis .................25

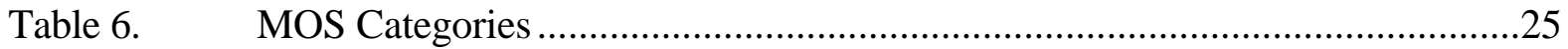

Table 7. The 1999 DoD Survey of Active Duty Personnel, Frequencies for Responses to the question, "How likely is it that you would choose to stay on active duty?" ..................................................................................26

Table 8. Male Junior Officers Pay Grade Distribution in the Whole Army and in Thesis Sample, "After [Ref. 37]"................................................................27

Table 9. The 1999 DoD Survey of Active Duty Personnel, Frequencies for Responses to the question, "How much do you agree/disagree with the statement? It would be easy for me to get a good civilian job if I left the military now."

Table 10. The 1999 DoD Survey of Active Duty Personnel, Mean and Standard Deviation Distribution of Responses to the question, "How satisfied are you with each of the following?"

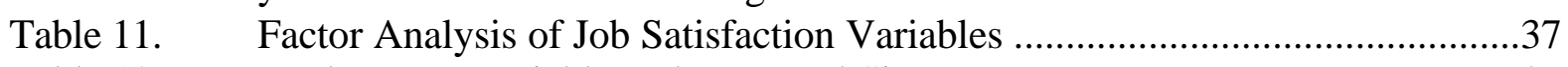

Table 12. Explanatory Variable and Expected Signs .....................................................

Table 13. Logistic Regression Results for Junior Male Army Officers.........................40

Table 14. Characteristics of the Base Case Individual.................................................42

Table 15. Partial Effects of Significant Explanatory Variables ......................................42

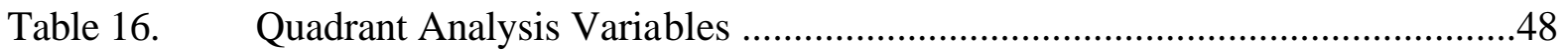


THIS PAGE INTENTIONALLY LEFT BLANK 


\section{ACKNOWLEDGMENTS}

I would like to deeply thank Kathryn Kocher for her enduring patience and timely remarks and inputs to this thesis. A student could not ask for a better thesis advisor. Without her expertise and guidance, this thesis would not have been completed.

In addition, I would like to thank Professor George W. Thomas for his knowledge and insight contributed greatly to the completion of this project.

I would also like to thank my loving mother and father for their never-ending support and love throughout this endeavor.

Last but not the least, I thank the Turkish Armed Forces for the opportunity to pursue a master's degree at the distinguished Naval Postgraduate School so that I can better serve my country. 
THIS PAGE INTENTIONALLY LEFT BLANK 


\section{INTRODUCTION}

\section{A. BACKGROUND}

The overriding objective of the United States Army is to train and retain quality personnel, both officer and enlisted, to achieve a more effective fighting force. Unfortunately, the US Army has recently been facing critical recruiting and retention problems due to the ever-changing factors in the civil and military worlds. For example, since the economy of the late 1990s performed remarkably well and unemployment remained low, recruiters struggled to attract new personnel. Another complicating factor for the All-Volunteer Force (AVF) has been the ever-increasing number of young adults seeking a college degree instead of a military career, a trend that further reduced the military's recruiting market. Paradoxically, while the military's requirement for highly educated personnel has increased in direct proportion to the increase in war-fighting technology, the number of college-educated recruits has diminished. Consequently, recruiting young men and women has become harder than ever before. Owing to these factors, the Army has missed its recruiting goal and military personnel planners believe that manning the "career force" beyond the first-term in a robust economy has worsened military retention and entry-level recruiting.

When confronting the cause of their manpower retention problems, military personnel experts have scrutinized internal factors such as leadership, operational tempo, and work hours as well as external factors, such as the military-civilian pay ratio and unemployment rate for long-term solutions to the career force-manning problem. [Ref. 24]

These experts have focused primarily on the issues of retention and turnover because each issue has monetary and non-monetary implications for the military services. From a monetary perspective, turnover is expensive. Recruiting, classifying, and training replacements cost money. From a non-monetary perspective, excessive turnover also results in lost experience, lower productivity, and reduced readiness. Since the military does not often allow lateral entry, a decline in retention rates could create a shortage of experienced personnel. These shortages could reduce the overall capability of the 
military, which would lead to a reduced pace of operations. [Ref. 13] Thus sustaining the Army at the current levels of operational capability depends on the Army's ability to recruit and to retain qualified personnel.

Past research shows that many factors, including demographic characteristics, job satisfaction, family situation, and job alternatives, affect turnover rates. Manpower planners in the services have experimented with many different incentives to improve overall retention. Monetary compensation incentives, quality of life improvements, and expanded promotion opportunities are among these incentives. Although pecuniary factors are quite important for one's stay/leave decision in the military, research shows that many service members stay in the military due to their taste for national service, training, camaraderie, and other non-monetary aspects. These factors should not be underestimated.

Retention decisions are different for officers than they are for enlisted members. For enlisted personnel, these decisions are based on specific interests within an individual's military career. Enlisted personnel join the service of choice for a contracted period of time, from two years for some Army occupational specialties to as many as six years for Navy and Air Force specialties. Once the contracted service requirement is fulfilled, the enlisted member makes one of three choices: (1) extend or reenlist for another specific period of obligated service, (2) leave the active force and join one of the reserve forces, or (3) leave the service altogether. [Ref. 27]

For officers, the situation is different in some respects. Upon entry into service, new ensigns or second lieutenants also agree to remain on active duty for a specific period of time. However, once they reach their End of Obligated Service (EOS), officers can continue to serve on active duty without incurring another contracted period of obligated service. The ability to remain on active duty depends on the type of commission. Officers with regular commissions can continue indefinitely as long as they are promoted. Officers with reserve commissions must apply to be "augmented" into the regular officer corps, or apply for extensions. If an Army captain with a reserve commission is extended and is selected for promotion to major, then he or she is automatically "augmented" and receives a regular commission as a major. [Ref. 27] 
This thesis primarily focuses on the retention intentions of junior Army officers who are serving within their initial obligated service requirement. These officers are of critical importance because they supervise, manage, and train enlisted soldiers on a daily basis. The performance of these officers ultimately affects the readiness and capabilities of all Army units.

In order to retain trained and qualified personnel in the service, manpower planners design surveys to identify the significant factors that affect the individual's decision to remain on active duty. Using these surveys results, the manpower planners project future retention levels and plan for shortfalls in critical occupational specialties.

\section{B. PURPOSE}

The purpose of this thesis is to develop a model that will identify the major factors affecting the retention of junior Army officers and will suggest a policy to reduce personnel costs and increase effectiveness. Retention, in this study, is defined as the individual officer's intention to remain on active duty after completing his or her initial obligation. The term "initial obligation" refers to the contractual period of service that an individual officer incurs. The length of this initial obligated service varies between three to seven years, depending on one's occupational specialty and/or on the commissioning source.

This thesis uses responses to the 1999 DoD Survey of Active Duty Personnel [Ref. 36] to estimate the models. The survey includes data on reenlistment intentions of service members. Past research has shown that a member's intentions are a good predictor of reenlistment behavior. Multivariate regression analysis is used to identify the factors that significantly affect the intention to reenlist and to assess their relative importance. The Statistical Analyze Software (SAS) package is used to analyze the data.

Specifically, this research answers these questions:

1. What factors affect the career intentions of junior Army officers who are within their initial period of obligated service? 
2. What is the relative importance of these factors in explaining the intention to remain on active duty?

3. How do these factors differ among Military Occupational Specialty (MOS) groups?

4. What policies may be effective for the Army to examine the retention of junior officers? 


\section{REVIEW OF LITERATURE}

\section{A. REENLISTMENT INTENTION AND ACTUAL BEHAVIOR}

The desire to predict human behavior accurately has always been an important priority in the fields of psychology, economics, and statistical analysis. The capability of understanding human behavior is a powerful tool. This tool proves to be very useful to large organizations and companies, which rely on feedback from employees in order to improve manpower policies. [Ref. 23] Just like these companies, the United States Army relies on information obtained from its current enlistees and officer corps to understand what factors cause these individuals to remain in or depart from the service.

Naturally, trying to predict the probability that an individual member will leave the service upon completion of his or her existing contract is difficult and such predictions are not always accurate. Sampling a representative portion of Army personnel through the use of a survey that asks about intentions can simplify and perfect the task. Members usually have a definite opinion of the military and know whether they would like to reenlist or not reenlist long before their contracts end.

Various studies have been conducted comparing the intentions of individuals to stay with their actual retention behavior. The question arises as to whether "intention" is a casual variable that affects all other variables leading to the individual's decision to remain on the job or to quit. As a result, attempting to capture people's intentions that reflect their aggregate feelings about their jobs is difficult. For example, when surveys are conducted, the individuals may be answering the "intent to remain on the job" question with a recent incident in mind-one that might skew their otherwise neutral opinion of their level of satisfaction. Despite the possible existence of this type of bias, Rearden revealed in her study that apparently the day-to-day occurrences at work do not noticeably affect an individual's intention to remain at the job or quit. [Ref. 23] 
In this respect, according to Doering and Grissmer, currently the most effective approach to studying retention is to survey individuals systematically about their reenlistment intentions at various times prior to the actual decision. If the survey that measures intentions also contains information about possible reasons for the decision, either for or against reenlistment, and if the intentions and behavior can be related with some degree of confidence, a policy-relevant analysis can be conducted. [Ref. 6]

According to Aizen and Fishbein [Ref.1], an individual's intention is generally the immediate and most accurate determinant of behavior, but certain conditions must exist:

a. There must be a correspondence between the measure of intention and the measure of behavior as to target (i.e. the job), the action (i.e. reenlist or leave), the time (i.e. at the end of current enlistment term), and the context (i.e. military).

b. Intentions change over time. The longer the time interval, the less accurate is the prediction of behavior from intention. In other words, the closer to the decision point, the more accurate is the intention as a predictor of behavior.

c. Aggregate intentions are much more stable than individual intentions over time, because incidents that hit individuals—such as injuries, illness, pregnancy, money losses, etc.- are likely to balance out at the aggregate level. Predictions of behavior from intentions at the aggregate level are therefore often remarkably accurate.

Also, according to another study completed by Mobley, Horner, and Hollingsworth [Ref. 16], employees' intentions to remain on the job or to quit do affect their actual behavior. This study shows that job dissatisfaction affects intentions to quit and intentions to search for a new job. Both of these intentions then affect the individual's actual behavior. Mobley's conclusion supports the idea that intention is a powerful factor when deciding to stay or to leave an organization.

Similarly, a study conducted by Szoc and Seboda [Ref. 25] sampled military members using a survey similar to The 1999 DoD Survey and the results of the survey were paired with subsequent behavior data. Items in the survey were classified as follows: 
- demographic characteristics,

- family considerations,

- housing,

- transportation,

- work conditions,

- financial information,

- satisfaction with Navy life,

- factors associated with the retention decision.

In order to ascertain the retention behavior of the individuals in the study, the authors used the Enlisted Personnel System Tracking File, which is maintained by Naval Military Personnel Command (NMPC). The findings revealed that the intention variable is a very powerful one: the model that included intentions enhanced the predictive quality of the model. The non-intentions model predicted reenlistment behavior accurately 66 percent of the time, whereas the intentions model predicted reenlistment behavior correctly 73 percent of the time. This study concluded that intentions do accurately predict retention behavior.

Other findings on the intention and behavior issue from the study of Szoc and Seboda include:

- Many more respondents stayed than had intended to do so.

- Those intending to leave were most likely to change their minds, and those who were undecided tended to stay.

- Most of those who left had intended to do so. For the group that stayed, almost half had not indicated this as their original intention.

- Of those who clearly intended to stay, only one-fourth changed their minds. [Ref. 25]

Royle and Robertson show that stated intent to remain on active duty is a superior predictor of actual retention when compared to indirect measures of job satisfaction such as pay, the work itself, or the organization. Stated intent is superior because it is a composite of the specific satisfiers important to each individual. Intent to remain in an 
organization may be useful as a criterion, substituting for actual retention information because of the strong relationship between the two variables. However, because the intent to remain and actual retention are not perfectly correlated, results from surveys using intent should be validated using actual retention data. Even if satisfaction with the job itself and satisfaction with the organization are highly related to intent to remain, other factors such as the external job market can have an overriding effect on the subsequent, actual decision. [Ref. 24]

Another analysis that examines the link between intentions and actual behavior is a Naval Postgraduate thesis by Anne-Marie Rearden. In her study, she explores whether reenlistment intentions can help to predict actual reenlistment behavior. She constructs multivariate models consisting of demographic, reenlistment intentions, and job satisfaction variables. The results show that reenlistment behavior is influenced by race, age, pay grade, marital status, enlistment period, and the level of satisfaction with the military in general. The results also shows that the most powerful predictor of reenlistment behavior is the reenlistment intention variable. [Ref. 23]

This thesis uses data from the 1999 DoD Survey of Active Duty Personnel to develop an econometric model to predict Army junior officer reenlistment behavior. Due to the relatively recent fielding of the survey, this thesis is unable to test the validity of intention stated on a survey as a predictor of actual retention behavior. The research cited above supports the use of an econometric model based on intentions as an accurate predictor of individual retention behavior. However, the results of the econometric model should be confirmed when actual turnover behavior information becomes available. Did the member reenlist or did he leave the military service? Does his or her actual behavior match his or her intentions? The validation of a model designed to predict reenlistment intentions can only occur when follow-on data is used to compare the members' intentions with their actual behavior.

\section{B. TURNOVER THEORY}

Turnover can be classified by its controllability, its measurement, and its effect on an organization, and may be categorized as either "functional or dysfunctional." Functional turnover, so called because its organizational benefits outweigh its costs, can 
occur when an unproductive worker resigns or is fired. Beyers, et al., summarize functional turnover: "A certain level of turnover promotes innovation, improved adaptation to technology, savings in wages and seniority pay, and other benefits to an organization." [Ref. 4] Dysfunctional turnover, which occurs when costs are higher than benefits, can occur when excessive recruiting, selection, and training costs result from a high degree of turnover. Turnover is also classified as voluntary or involuntary. If an individual resigns, it is voluntary. Involuntary turnover occurs when an individual is fired. Most organizations, including the military, are interested in the causes of voluntary turnover, since it frequently is also dysfunctional. This thesis addresses voluntary turnover.

Experts often assume that voluntary turnover stems from an employee's dissatisfaction with a job. However, Lensing demonstrated this assumption is not necessarily true, since people may voluntarily resign when work schedules interfere with family commitments or because they desire to return to school. A better job offer might also persuade workers to resign, even if they are not dissatisfied with their current jobs. [Ref.14] However, most research has shown that a strong relationship between job satisfaction and turnover exists.

Job satisfaction refers to an individual's general attitude toward his or her job. A person with a high level of job satisfaction holds positive attitudes toward the job while a person who is dissatisfied with his or her job holds negative attitudes toward the job. A study by Porter and Steers uncovered an inverse relationship between job satisfaction and turnover. They concluded that expressed "intention to leave" might represent the next logical step after experienced dissatisfaction. [Ref. 22]

Locke (1976) reported consistent and significant, but not especially high correlations between job satisfaction and turnover, as did Mobley (1977), who found a significant and consistent relationship between job satisfaction and turnover. According to Mobley, one of the primary consequences of job dissatisfaction is that it stimulates thoughts of quitting, leading the worker to evaluate the expected prospects of a search, the intention to search, the search, the evaluation of alternatives, the intention to quit, and finally the withdrawal decision and behavior. Mobley evaluated a simplified heuristics 
model of the withdrawal decision process and found that intention to quit was the immediate precursor of actual withdrawal behavior. [Ref. 15]

Muchinsky determined that the magnitude of the satisfaction-turnover correlation, on average, is approximately -.40 , indicating that the more people dislike their jobs, the more likely they are to quit. This relationship is influenced by several factors, including the availability of other work. [Ref. 21]

Another important consideration in examining turnover is the extent of loyalty or commitment that an employee has to his employer. Organizational commitment is the degree of a person's identification with and involvement in an organization. The distinguishing features of commitment are "(1) a strong belief in and acceptance of the organization's goals and values; (2) willingness to exert effort for the organization and (3) a desire to maintain membership in the organization." [Ref 21]

Mowday and et al. studied commitment extensively by looking at the bonds between employees and their organizations. These bonds are established in an exchange between the individual and the organization. If an organization provides what an individual seeks - that which fulfill needs or desires - then organizational commitment is strengthened. Strong bonds are important from the organization's perspective because stronger bonds result in lower employee absenteeism and turnover, which in turn reduce costs and raise productivity. [Ref. 19]

Although job satisfaction and organizational commitment are the most widely cited causes of turnover, many others factors have been studied. Researchers frequently use models to conceptualize these causes and to provide a framework in which to examine the turnover process.

Mobley's turnover model is probably the most representative model of the current turnover research. Mobley's work was, in the words of Muchinsky,

A major step forward in thinking of the process from job satisfaction to turnover instead of repeatedly accessing the direct relationship between dissatisfaction and turnover. [Ref. 20]

Mobley proposed the first version of this model in 1977 when he noted: 
The relationship between job satisfaction and turnover is significant and consistent, but not particularly strong. A more complete understanding of the psychology of the withdrawal decision process requires investigation beyond the replication of satisfaction-turnover relationship. [Ref. 15]

His paper generated much research. Since 1977, Mobley and many others have tested the variations of the model in an effort to explain turnover. Mobley's model differed from previous work in the proposal of intermediate steps between job satisfaction and the decision to quit. His turnover model, tested in 1978 by Mobley and et al., is shown in Figure 1. Specifically, this model suggests that dissatisfaction leads to thoughts of quitting. These thoughts lead to "rational evaluation" of the expected utility of search and of the cost of quitting. If there is a perceived chance of finding an alternative, the next step would be "intent to search." Intent to search then leads to "actual search." Alternatives are then evaluated and compared to the current job. If the comparison favors the alternative, "intent to quit" is stimulated, followed by "quitting." This model was tested with a sample of 203 hospital employees. Self-reported intention to quit was an important influence on turnover.

Mobley found that the single significant regression coefficient with turnover was "intention to quit" and that the effect of job dissatisfaction was on "thinking of quitting" and "intentions" rather than on "turnover" itself. [Ref. 16] 


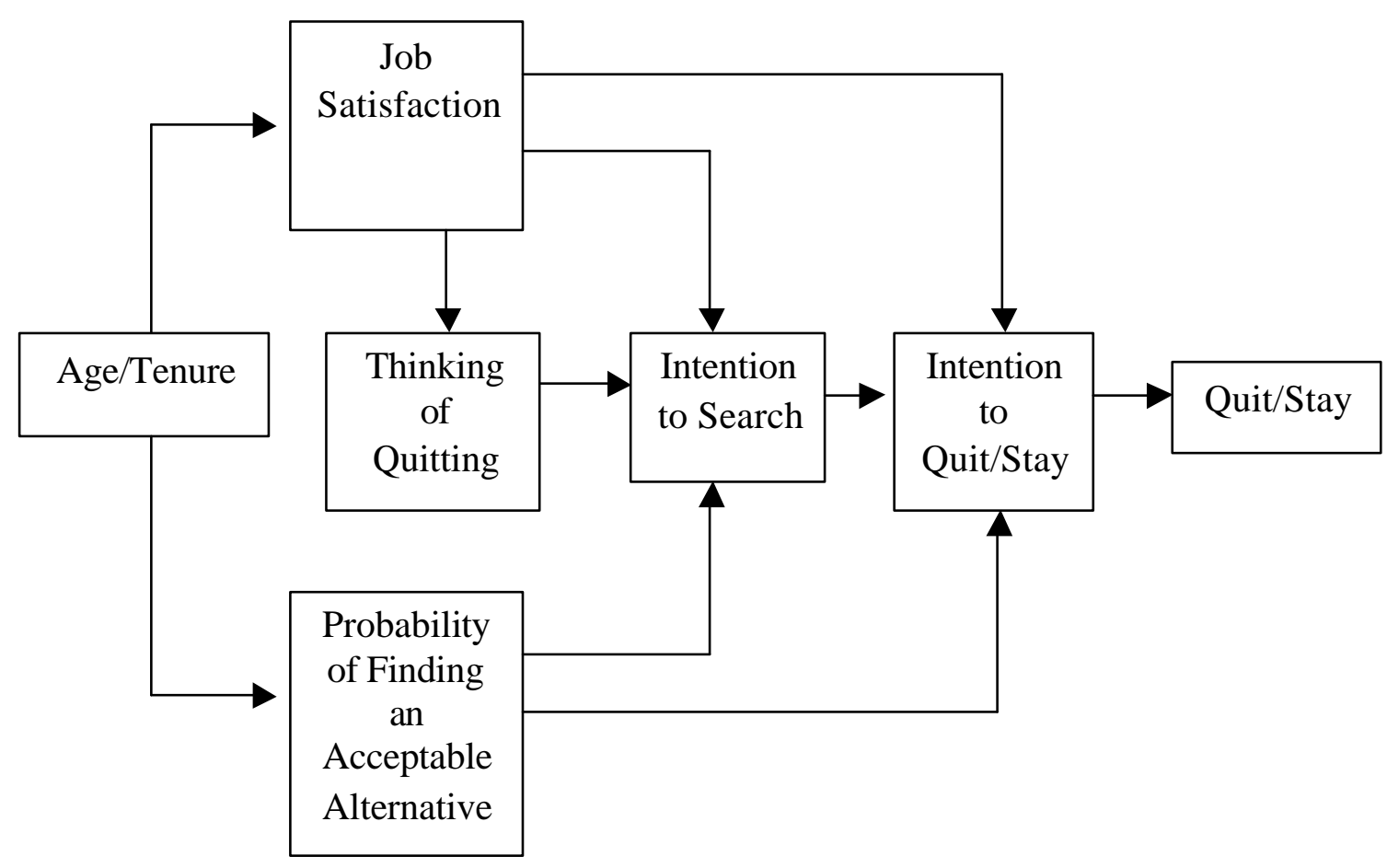

Figure 1. Mobley and et al. Turnover Model, "After [Ref.16]"

Several other conceptual models have been tested. These models are similar to Mobley's in that they evaluate an individual's present position that creates dissatisfaction and leads to a search for another job. This dissatisfaction and job search result in intentions to quit. Intentions to quit will ultimately lead to a decision to quit for those individuals who also perceive a favorable labor market with alternative jobs providing more benefits than their current job.

\section{MILITARY TURNOVER RESEARCH}

Research on turnover in the military has been separated from research concerned with turnover in the private sector owing to several unique characteristics of the withdrawal process in the military. First, every member of the military must make an explicit decision to remain or to leave at some point during his or her tenure. Generally, civilian employees are not expected to make such a specific decision (especially if they decide to stay). Also, because military employment is based on contracts, the decision to 
leave the military comes at a single, predictable point in time. In the private sector an employee may intend to quit but be uncertain about when. Reenlistment in the military also means an obligation to remain for a fixed term. Consequently, the decision to reenlist carries greater commitment than does the decision to remain on the job in the private sector. [Ref. 13]

Also, military occupations have many unique features that are not frequently experienced in the civilian world. Probably more than most occupations, the military employees' families are affected by the worker's employment. For example, military members are subject to frequent moves, which can be very disruptive to family life. Children's education and social development can be affected, spouses' employment may be disrupted and extended family and friendships are broken. Other aspects of military life that may affect employment decisions include the requirement to be away from home frequently, living in the field, long working hours and weekend work with no direct effect on take-home pay, danger, military discipline and loss of constitutional rights, and the requirement to lay down one's life should the situation demand it. [Ref. 10] All of these factors potentially influence the military personnel's decisions to quit or to stay. For such reasons researchers should study military turnover behavior separately from private sector turnover behavior.

In 1985 Hayden conducted a study using the 1978 DoD Survey of Officers and Enlisted Personnel [Ref. 33] to determine factors influencing the career decisions of Army officers with one through three years of service. The officers were divided into three occupational groups: combat arms, combat support, and combat service support. Using regression models and discriminant analysis with "expected years of service" as the dependent variable, Hayden found that overall satisfaction with military life was the most important factor influencing retention. Beyond this, the different occupational groups had different specific factors affecting retention, but most were based on comparing military to civilian life. [Ref. 9]

Theilmann (1990) analyzed Marine Corps officer separation behavior for officers in their initial period of obligated service. For this study Theilmann used information contained in the 1985 DoD Survey of Officer and Enlisted Personnel [Ref. 34] matched 
with subsequent retention data obtained from the Defense Manpower Data Center (DMDC). Regarding the leave or stay decisions, Theilmann analyzed the effect of intrinsic and extrinsic job satisfaction factors, satisfaction with benefits, current location, and community attitudes. He concluded that

The factors that most strongly influence male junior officers to remain on active duty beyond their initial service obligation are their commissioning source, marital/dependent status, military occupational specialty and intrinsic and extrinsic job satisfaction factors. [Ref. 27]

Dudley and Hoyle conducted a study to find what types of rewards Army and Marine Corps officers valued and how these awards affected retention. In this study, 92 Army and 119 Marine Corps officers, in the ranks O- 1 through O-4, were given a list of 41 rewards. Using a one-to-five scale, he asked the officers to rank the expected probability and importance of receiving such rewards during their careers. He also asked them to rank the influence of each award on their decision to stay in or leave the service. The results for the Army were similar to those of the Marine Corps. They found that while extrinsic factors (financial security, job security, pay, promotion, and fringe benefits) were important to the officers, intrinsic factors (trusted by subordinates and superiors, interesting job, respected by superiors, responsibility and authority, pride in self, supportive atmosphere, accomplishments, etc.) were considered much more important. Dudley and Hoyle also found that the factors the officers considered most important were also most important in determining career intentions. In addition, the expected probability of receiving these rewards was highly correlated with the officers' career intentions. [Ref. 7]

Vranken and et al. addressed a major Army issue: deployment and its effects on the immediate family. Of the spouses surveyed, $80 \%$ had children and $50 \%$ of the sample had been married less than two years. It was noted that the spouses' attitudes toward the Army and their husbands' careers changed once the husbands were deployed. ${ }^{1}$ Their feelings toward the Army shifted from a very positive attitude to a more neutral tone. Thirty-one percent of the wives felt that the family separation had affected their

\footnotetext{
${ }^{1}$ Only male Army officers were included.
} 
marriages negatively. [Ref. 28] This could possibly result in a trade off between divorce and staying.

Junior officers today place more of a priority on preserving the family unit in their decision to stay or to leave the military. To boomer officers, (born between 1943 and 1960) taking care of families entailed constructing state-of-the art day care facilities for kids and building large PXs (post exchanges) for the spouses. To Generation Xers, (born between 1960 and 1980) taking care of families entailed giving officers time to nurture relationships with children and spouses. [Ref. 31] Armstrong (2000), in studying changing demographics and the impact on officer retention, discovered that improving family support programs was an important step in modifying career progression plans for officers. She recommended that the military should consider adopting family support programs that had been implemented by other armed forces, such as the Royal Australian Armed Forces, and/or implement a dual-track career progression program that allowed officers to choose the options that provide a better balance between career and family without sacrificing certain career success. [Ref. 2]

Johnston conducted another study on turnover of junior Army officers. He used the 1985 DoD Survey of Officer and Enlisted Personnel [Ref. 34] and included various explanatory variables, such as personal characteristics (age, tenure, education, number of dependents), occupational characteristics (pay grade, military occupational specialty, time spent overseas), expectations concerning alternative employment (probability of better job offers, searched for work in last year), and satisfaction with the service. Johnston found that intentions to remain in the service are more strongly related to actual turnover behavior of junior Army officers in the short term than in the long term. [Ref. $10]$

Lakhani conducted a retention cost-benefit analysis of U.S. Army junior officers. He hypothesized that a junior Army officer's decision to stay or to leave the service can consist of three major considerations. The first consideration consists of monetary aspects such as pay, allowances, and retirement benefits. The second consideration consists of non-pecuniary benefits such as career commitment and satisfaction. The last consideration is comprised of various attributes that are difficult to measure, such as taste 
for Army life and the potential effects of satisfaction with family life on job satisfaction. Together these three factors form a utility maximization function, which suggests that a junior Army officer will stay in the service if the net benefit derived by these attributes exceeds the net benefit available from alternative civilian employment. [Ref. 12]

Zinner (1997) studied the factors affecting the retention of male junior Marine Corps officers who were serving within their initial period of obligated service. Zinner used a broad social science approach, which combined organizational and individual behavioral factors to model the turnover decision. Data for this study were drawn from a matched file of responses to the 1992 DoD Survey of Officers and Enlisted Personnel and Their Spouses [Ref. 35] with 1996 follow-up retention information from the Defense Manpower Data Center's Master loss file. The factors that significantly influenced the sample members' decisions to remain on active duty included:

- commissioning source,

- occupational specialty,

- deployment to Operation Dessert Shield/Storm,

- satisfaction with various intrinsic aspects of life in the Marine Corps,

- concerns with the force draw down,

- whether or not the officer had searched for civilian employment in the last twelve months,

- whether or not the officer believed that the skills he had acquired in the Marine Corps would be transferable to the civilian market,

- the influence on the career decision of the officer's spouse.[Ref. 32]

In reviewing these studies, a myriad of factors obviously contribute to the career decisions of Army junior officers. In addition to those cited, there are, undoubtedly, many other factors that have been overlooked and still others that have not been identified yet. However, all relevant factors fall into one of only three broad categories: personal, intrinsic, and extrinsic factors. Organizing this thesis on the basis of these categories will simplify the approach of determining which factors are most influential and may also help to reveal other potentially influential factors that have not yet been specifically 
considered. Table 1 summarizes the major findings of turnover research presented in this chapter.

Table 1. A Summary of Major Findings in Turnover Research

\begin{tabular}{|l||l|}
\hline \multicolumn{2}{|c|}{ REENLISTMENT INTENTION AND ACTUAL BEHAVIOR } \\
\hline \hline \multicolumn{1}{|c|}{ AUTHOR } & \multicolumn{1}{|c|}{ FINDING } \\
\hline \hline Aizen and Fishbein (1980) & $\begin{array}{l}\text { Individual intention is generally the immediate and } \\
\text { most accurate determinant of behavior, assuming there } \\
\text { is a correspondence between the measure of intention } \\
\text { and the measure of behavior as to target (i.e. the job), } \\
\text { the action (i.e. reenlist or leave), the time (i.e. at the } \\
\text { end of current enlistment term), and the context (i.e. } \\
\text { military). }\end{array}$ \\
\hline \hline Royle and Robertson (1980) & $\begin{array}{l}\text { Satisfaction with the specific job and satisfaction with } \\
\text { the organization are highly related to intent to remain } \\
\text { on the job, and subsequently related to their actual } \\
\text { decision. }\end{array}$ \\
\hline \hline Szoc and Seboda (1984) & $\begin{array}{l}\text { The intention variable enhances the predictive quality } \\
\text { of the model. }\end{array}$ \\
\hline \hline Doering and Grissmer (1985) & $\begin{array}{l}\text { If the survey measuring intentions also contains } \\
\text { information about possible reasons for the decision, a } \\
\text { policy-relevant analysis can be conducted. }\end{array}$ \\
\hline \hline Rearden (1988) & $\begin{array}{l}\text { The most powerful predictor of reenlistment behavior } \\
\text { is the reenlistment intention variable. }\end{array}$ \\
\hline
\end{tabular}


Table 1. A Summary of Major Findings in Turnover Research (Continued)

\begin{tabular}{|c|c|}
\hline \multicolumn{2}{|r|}{ TURNOVER THEORY } \\
\hline AUTHOR & FINDING \\
\hline Porter and Steers (1973) & $\begin{array}{l}\text { There is an inverse relationship between job } \\
\text { satisfaction and turnover. }\end{array}$ \\
\hline Mobley (1977) & $\begin{array}{l}\text { Dissatisfaction leads to thinking of quitting, intention } \\
\text { to search, intention to leave, and actual turnover. }\end{array}$ \\
\hline Mowday (1982) & $\begin{array}{l}\text { Strong linkages with the organization result in lower } \\
\text { employee absenteeism and turnover, which in turn } \\
\text { lead to reduced costs and higher productivity. }\end{array}$ \\
\hline Lensing (1984) & $\begin{array}{l}\text { A voluntary resignation can happen when work } \\
\text { schedules interfere with family commitments or a } \\
\text { better job offer is accepted. }\end{array}$ \\
\hline Muchinsky (2000) & $\begin{array}{l}\text { The satisfaction-turnover correlation is -. } 40 \text { indicating } \\
\text { the more a person dislikes his or her job, the more } \\
\text { likely he or she is to quit. }\end{array}$ \\
\hline \multicolumn{2}{|r|}{ MILITARY RESEARCH } \\
\hline AUTHOR & FINDING \\
\hline Dudley and Hoyle (1979) & $\begin{array}{l}\text { Intrinsic factors (trusted by subordinates and } \\
\text { superiors, interesting job, respected by superiors, } \\
\text { responsibility and authority, pride in self, supportive } \\
\text { atmosphere, accomplishments, etc.) were considered } \\
\text { much more important than extrinsic factors (financial } \\
\text { security, job security, pay, promotion, and fringe } \\
\text { benefits). }\end{array}$ \\
\hline Vranken (1984) & $\begin{array}{l}\text { Spouses' attitudes toward the Army influence career } \\
\text { decisions of military members. }\end{array}$ \\
\hline Hayden (1985) & $\begin{array}{l}\text { Overall satisfaction with military life is the most } \\
\text { important factor influencing retention. }\end{array}$ \\
\hline Johnston (1988) & $\begin{array}{l}\text { Intentions to remain in the service are more strongly } \\
\text { related to actual behavior of junior Army officers in } \\
\text { the short term than in the long term. }\end{array}$ \\
\hline
\end{tabular}


Table 1. A Summary of Major Findings in Turnover Research (Continued)

\begin{tabular}{|c|c|}
\hline \multicolumn{2}{|r|}{ MILITARY RESEARCH } \\
\hline AUTHOR & FINDING \\
\hline Lempe (1989) & $\begin{array}{l}\text { The decision to reenlist carries greater commitment } \\
\text { than does the decision to remain on the job in the } \\
\text { private sector due to the unique features of military } \\
\text { occupations such as being away from home } \\
\text { frequently, living in the field or military discipline. }\end{array}$ \\
\hline Theilmann (1990) & $\begin{array}{l}\text { Commissioning source, marital/dependent status, } \\
\text { military occupational specialty, and intrinsic and } \\
\text { extrinsic job satisfaction factors influence junior } \\
\text { Marine officer turnover. }\end{array}$ \\
\hline Zinner (1997) & $\begin{array}{l}\text { Commissioning source, occupational specialty, } \\
\text { deployment to Operation Desert Shield/Storm, } \\
\text { concerns with the force draw down, and officer's } \\
\text { spouse factors influence significantly member's } \\
\text { decision to stay on active duty. }\end{array}$ \\
\hline Armstrong (2000) & $\begin{array}{l}\text { Improving family support programs is an important } \\
\text { step in modifying career progression plans for } \\
\text { officers. }\end{array}$ \\
\hline
\end{tabular}


THIS PAGE INTENTIONALLY LEFT BLANK 


\section{MODEL DEVELOPMENT}

\section{A. DATA COLLECTION}

The most effective method with which to obtain information on planned retention is simply to ask individuals their intentions. Three general methods exist for querying a person: questionnaire, oral, or observational. [Ref. 29] In this research, using observational methods is impossible. Oral interviews also present limitations. While it would be desirable to interview each junior Army officer, such a method is not practical. Cost and time constraints preclude use of this reliable technique.

However, questionnaires offer many advantages. The most obvious is cost. Moser and Kalton ind icate the expense of printing questionnaires and distributing them to large numbers of people is considerable less than that of interviewing similar numbers of people. [Ref. 18] Also, Berdie and Anderson point out that researchers conducting personal interviews frequently have trouble contacting people not in their office during normal hours. Questionnaires delivered to their homes or offices allow respondents to complete the survey at their leisure, thus improving the response rate. [Ref 3]

A questionnaire format was used as the most practical means of data collection for the series of surveys of military personnel begun in 1978. Goode and Hatt [Ref. 8] observed that the use of questionnaires in research is based on one basic, underlying assumption: the respondent will give truthful answers. An important additional issue for this survey questionnaire is how accurately actual retention is measured by an individual's stated intentions.

\section{B. SURVEY DESCRIPTION}

The data used in this thesis were drawn primarily from the 1999 DoD Survey of Active Duty Personnel. [Ref. 36] The Defense Manpower Data Center (DMDC) conducted this survey to assess perceptions of military life issues, at the request of the

Office of the Deputy Assistant Secretary of Defense for Personnel Support, Families, and Education. 
The 1999 DoD Survey of Active Duty Personnel survey contains 112 questions (some with multiple items). A copy of the survey is attached in the Appendix. The survey's items can be grouped broadly into several categories: assignment information, career information, military life, programs and services, family information, economic issues, and background information. These categories are described in Table 2.

Table 2. Survey Categories

\begin{tabular}{|l|l|}
\hline Assignment Information & $\begin{array}{l}\text { Questions on hours worked, permanent duty station } \\
\text { (PDS), satisfaction with characteristics of the PDS, } \\
\text { permanent change of station moves, and time away from } \\
\text { the PDS for military duties. }\end{array}$ \\
\hline Career Information & $\begin{array}{l}\text { Questions on career intent, reasons for joining, obligation } \\
\text { and retention, satisfaction with occupational specialty, } \\
\text { and satisfaction with aspects of military service. }\end{array}$ \\
\hline Military Life & $\begin{array}{l}\text { Questions on importance of military activities, thoughts } \\
\text { of leaving the military, civilian vs. military opportunities, } \\
\text { and overall satisfaction. }\end{array}$ \\
\hline Programs and Services & $\begin{array}{l}\text { Questions on the availability and use of on-base and off- } \\
\text { base services, facilities, and programs. }\end{array}$ \\
\hline Family Information & $\begin{array}{l}\text { Questions on marital status, spouse occupation and } \\
\text { education, dependents, childcare arrangements, and } \\
\text { military health care. }\end{array}$ \\
\hline \hline Economic Issues & $\begin{array}{l}\text { Questions on non- military income, total monthly income } \\
\text { and expenses, savings and debt, service and retirement } \\
\text { benefits. }\end{array}$ \\
\hline \hline Background & $\begin{array}{l}\text { Information on gender, race/ethnic status, education, duty } \\
\text { status, Service, pay grade, and time served. }\end{array}$ \\
\hline
\end{tabular}

The population from which the survey members were sampled consisted of active duty officers and enlisted personnel from the Army, Navy, Marine Corps, Air Force, and Coast Guard who were stationed in the United States or overseas in May 1999. Initially, 66,040 active duty members were targeted. However, only 33,189 individuals from all four military services returned usable surveys. The (weighted) response rate was $51 \%$, which is typical for large-scale surveys of DoD military personnel. [Ref. 36] The survey 
was designed to aid in examining enlistment and retention decisions, career orientation, and policies affecting military members and their families. The sample design was stratified by service, gender, pay grade group, location and marital status. When considering only Army active duty officers, the sample size (prior to any data cleaning) was 5,931 , of which $79 \%$ were male. Table 3 depicts the survey stratification for all officers by service and sex.

Table 3. Gender and Branch of Service

\begin{tabular}{|l|r|r|r|r|r|r|r|}
\hline \multicolumn{9}{|c|}{1999 ACTIVE DUTY OFFICER SAMPLE ALLOCATION } \\
\hline \hline Gender & Total & Army & Navy & $\begin{array}{c}\text { Marine } \\
\text { Corps }\end{array}$ & $\begin{array}{c}\text { Air } \\
\text { Force }\end{array}$ & $\begin{array}{c}\text { Coast } \\
\text { Guard }\end{array}$ \\
\hline \hline Male & 13,235 & 4,688 & 2,518 & 2,156 & 3,287 & 586 \\
\hline \hline Female & 2,758 & 1,243 & 431 & 164 & 825 & 95 \\
\hline Total & 15,993 & 5,931 & 2,949 & 2,320 & 4,112 & 681 \\
\hline
\end{tabular}

$\mathrm{N}=31986$

\section{MODEL DATA DESCRIPTION}

Since the focus of the research is junior Army officers with pay grade between O1 and O-3, a sub-sample of 1,169 active duty junior Army officers who are within their initial period of obligated service was selected from the survey for use in this thesis. These company-grade officers (pay grades between O-1 and O-3) represent the majority of the officers who would be within their initial period of obligated service. Many warrant officers and majors (O-4) and above have already completed their initial obligation. Table 4 displays the distribution of company-grade officers.

Table 4. Company-Grade Officers Pay Grade Distribution

\begin{tabular}{|c|c|c|c|c|}
\hline \multirow{2}{*}{ Pay Grade } & \multicolumn{2}{|c|}{ Female } & \multicolumn{2}{c|}{ Male } \\
\cline { 3 - 5 } & Frequency & Percent & Frequency & Percent \\
\hline \hline O-1 & 60 & 26.66 & 246 & 26.06 \\
\hline O-2 & 103 & 45.78 & 457 & 48.41 \\
\hline O-3 & 62 & 27.56 & 241 & 25.53 \\
\hline
\end{tabular}

$\mathrm{n}=1169$ 
The term " initial obligation" represents the contractual period of service required by a particular commissioning program plus any further obligation incurred due to some form of follow-on training (such as flight school). For example, West Point Military Academy graduates have a five-year commitment, Army Reserve Officer Training Corps graduates have a four-year obligation and Officer Candidate School graduates face a three-year obligation.

Officers with no obligated service were deleted from the sample, due to the fact that they are essentially "careerists" who have already made committal stay/leave decisions. The factors influencing their retention are likely to be different from the factors influencing those within obligated service.

The sample used in this study was narrowed further by deleting junior female active duty officers from the model. Female officers account for $19.25 \%$ of the sample of junior Army officers within their obligated service. This percentage is similar to the proportion of women junior officers in the Army as a whole (16.77\% in FY 1999). [Ref. 37]

Extensive preliminary analyses showed the existence of important behavior differences between males and females. Women have markedly different reenlistment patterns, given the differential occurrence and impact of factors, such as marriage and childbearing, spouse conflict, migration and physical ability. Thus, separate models should be undertaken to explain female and male retention intentions. This thesis is limited to an analysis of male officers' retention due to the sample size considerations.

The majority of the sample respondents, $54.41 \%$, are single with no dependents. This precluded including family related questions that would have restricted the number of cases for analysis to married members and/or those with dependents, which is not the purpose of this study.

Respondents who did not provide valid responses for items essential to the analysis were eliminated from the data set. The final sample for analysis contained 680 male junior Army officers. Table 5 displays the distribution of male junior Army officers by pay grade for our final sample for analysis. 
Table 5. Male Junior Officers Pay Grade Distribution for Thesis Analysis

\begin{tabular}{|c|c|c|}
\hline Pay Grade & Frequency & Percent \\
\hline O-1 & 120 & 17.65 \\
\hline O-2 & 378 & 55.59 \\
\hline O-3 & 182 & 26.76 \\
\hline
\end{tabular}

$n=680$

Table 6 describes the Military Occupational Specialties (MOS) of the sample. These are categorized as combat, combat support, and combat service support branch. Combat arms comprise the biggest category with $51.18 \%$.

Table 6. MOS Categories

\begin{tabular}{|l|l|c|}
\hline \multicolumn{2}{|c|}{ OFFICER OCCUPATION AREAS } & PERCENT \\
\hline \hline Combat & $\begin{array}{l}\text { Include Tactical Operation Officers such as } \\
\text { Infantry, Armor, and Artillery. }\end{array}$ & 51.18 \\
\hline \hline Combat Support & $\begin{array}{l}\text { Include Officers from Intelligence, Engineering } \\
\text { and Maintenance, and Health Care. }\end{array}$ & 31.47 \\
\hline \begin{tabular}{l|l|} 
Combat Service \\
Support
\end{tabular} & $\begin{array}{l}\text { Include Officers from Supply and Procurement, } \\
\text { Administration Service, and Scientific Research. }\end{array}$ & 16.91 \\
\hline
\end{tabular}

$n=680$

The 1999 DoD Survey of Active Duty Personnel asks, "Suppose that you have to decide whether to stay on active duty. Assuming you could stay, how likely is it that you would choose to do so?" Available responses are categorized from "very likely" to "very unlikely." The response to this questionnaire item represents the behavior of interest, and it is used as the dependent variable for the multivariate retention model estimated in this thesis. Frequencies for responses to this question are shown in Table 7. 
Table 7. The 1999 DoD Survey of Active Duty Personnel, Frequencies for Responses to the question, "How likely is it that you would choose to stay on active duty?"

\begin{tabular}{|l|c|c|}
\hline \multicolumn{1}{|c|}{ Responses } & Frequency & Percent \\
\hline \hline Very Likely & 99 & 14.56 \\
\hline \hline Likely & 134 & 19.71 \\
\hline Neither Likely/Unlikely & 132 & 19.41 \\
\hline Unlikely & 147 & 21.62 \\
\hline Very Unlikely & 168 & 24.71 \\
\hline
\end{tabular}

$n=680$

As can be seen in Table 7, $14.56 \%$ of the male Army officers responding to the survey indicated that they were very likely to stay on active duty at the end of their initial obligated service, while $24.71 \%$ indicated that their chance of staying on active duty was "very unlikely." The rest of the respondents were approximately evenly distributed among the choices ranging from likely to unlikely.

The majority of respondents categorized their race/ethnic group as White (82.95\%), while only $4.85 \%, 3.53 \%$, and $8.97 \%$ of the respondents categorized themselves as Black, Hispanic, and other race, ${ }^{2}$ respectively. Black and Hispanic officers are under-represented in this sample relative to the active Army officer corps as a whole where Blacks and Hispanics accounted for $11.5 \%$, and $4.4 \%$ of the total, respectively, in 1999. [Ref. 37] In this respect, White and other race were over-represented where White and other race accounted for $77.68 \%$, and $6.36 \%$ of the total, respectively, in 1999 . (However, there is no clear explanation for this uneven distribution.) Table 8 displays the distribution of male junior Army officers in the whole Army and is our final sample in this thesis.

2 The "other race" category represents American Indians, Alaskan Natives, and Asian/Pacific Islanders. 
Table 8. Male Junior Officers Pay Grade Distribution in the Whole Army and in Thesis Sample, "After [Ref. 37]"

\begin{tabular}{|l|c|c|c|c|}
\hline \multicolumn{1}{|c|}{ Race/Ethnicity } & \multicolumn{2}{|c|}{$\begin{array}{c}\text { Pay Grade between O-1 and } \\
\text { O-3 in the Whole Army }\end{array}$} & $\begin{array}{c}\text { Pay Grade between O-1 and } \\
\text { O-3 in the Thesis Sample }\end{array}$ \\
\cline { 5 - 6 } & Frequency & Percent & Frequency & Percent \\
\hline White & 30,132 & 77.68 & 562 & 82.65 \\
\hline Black & 4,471 & 11.52 & 33 & 4.85 \\
\hline Hispanics & 1,718 & 4.42 & 24 & 3.53 \\
\hline \hline Other & 2,466 & 6.36 & 61 & 8.97 \\
\hline Total & 38,787 & $100.00^{*}$ & 680 & $100.00^{*}$ \\
\hline
\end{tabular}

Table 9 displays responses to a question about how much the respondents would agree or disagree that they could find a good civilian job easily if they left the military now. As Table 9 shows, the majority of male junior officers $(56.18 \%)$ believe that they could find a better job in the private sector if they left the military.

Table 9. The 1999 DoD Survey of Active Duty Personnel, Frequencies for Responses to the question, "How much do you agree/disagree with the statement? It would be easy for me to get a good civilian job if I left the military now."

\begin{tabular}{|l|c|c|}
\hline \multicolumn{1}{|c|}{ Responses } & Frequency & Percent \\
\hline \hline Strongly Agree & 382 & 56.18 \\
\hline Agree & 199 & 29.26 \\
\hline Neither Agree/Disagree & 68 & 10.00 \\
\hline \hline Disagree & 24 & 3.53 \\
\hline Strongly Disagree & 7 & 1.03 \\
\hline
\end{tabular}

$n=680$

The 1999 DoD Survey of Active Duty Personnel asks the respondents to asses satisfaction with a series of specific job facets. Table 10 displays mean and standard deviation distribution of responses to the question of, "How satisfied are you with each of

\footnotetext{
* Percent is not 100 due to rounding error
} 
the following?" The respondents are mostly satisfied with job security by 3.83 mean value.

Table 10. The 1999 DoD Survey of Active Duty Personnel, Mean and Standard Deviation Distribution of Responses to the question, "How satisfied are you with each of the following?"

\begin{tabular}{|c|c|c|}
\hline Satisfaction Variables & Mean & $\begin{array}{l}\text { Standard } \\
\text { Deviation }\end{array}$ \\
\hline Basic Pay & 2.95 & 1.17 \\
\hline Special and Incentive Pay & 2.66 & 1.20 \\
\hline Reenlistment Bonus/ Continuation Pay Program & 2.11 & 1.01 \\
\hline Housing Allowance & 2.97 & 1.19 \\
\hline Medical Care for You & 3.07 & 1.20 \\
\hline Dental Care for You & 3.28 & 1.12 \\
\hline Retirement Pay & 2.43 & 1.12 \\
\hline Cost of Living Adjustments (COLA) to Retirement Pay & 2.59 & 0.98 \\
\hline $\begin{array}{l}\text { Other Retirement Benefits (Medical Care and Use of Base } \\
\text { Services) }\end{array}$ & 2.72 & 1.11 \\
\hline Pace of Your Promotions & 3.48 & 0.91 \\
\hline Chances for Future Advancement & 3.61 & 0.88 \\
\hline Training and Professional Development & 3.25 & 1.07 \\
\hline Type of Assignment Received & 3.33 & 1.08 \\
\hline Deployments & 2.82 & 1.03 \\
\hline $\begin{array}{l}\text { Other Military Duties That Take You Away from } \\
\text { Permanent Duty Station }\end{array}$ & 2.93 & 0.92 \\
\hline Availability of Equipment, Parts, and Resources & 2.28 & 1.03 \\
\hline Level of Manning in Your Unit & 2.21 & 1.02 \\
\hline Your Unit's Morale & 2.86 & 1.15 \\
\hline Your Personal Workload & 2.93 & 1.05 \\
\hline Amount of Personal/Family Time You Have & 2.54 & 1.14 \\
\hline Off-Duty Educational Opportunities & 2.64 & 1.08 \\
\hline Quality of Leadership & 3.12 & 1.10 \\
\hline Military Values, Lifestyle, and Tradition & 3.42 & 1.03 \\
\hline \multicolumn{3}{|c|}{$\begin{aligned} \text { Value Coding: } 1=\text { Very Dissatisfied; } 2=\text { Dissatisfied; } \\
\text { 3=Neither Satisfied/Dissatisfied; } 4=\text { Satisfied; } 5=\text { Very Satisfied }\end{aligned}$} \\
\hline
\end{tabular}


Table 10. The 1999 DoD Survey of Active Duty Personnel, Mean and Standard Deviation Distribution of Responses to the question, "How satisfied are you with each of the following?" (Continued)

\begin{tabular}{|l|c|c|}
\hline \multicolumn{1}{|c|}{ Satisfaction Variables } & Mean & $\begin{array}{c}\text { Standard } \\
\text { Deviation }\end{array}$ \\
\hline \hline Amount of Enjoyment from Your Job & 3.12 & 1.15 \\
\hline \hline Frequency of PCS Moves & 3.15 & 0.88 \\
\hline \hline Job Security & 3.83 & 0.76 \\
\hline
\end{tabular}

Value Coding: 1= Very Dissatisfied; 2= Dissatisfied;

3=Neither Satisfied/Dissatisfied; 4= Satisfied; 5= Very Satisfied

$n=680$

\section{HYPOTHESIZED RETENTION MODEL}

A conceptual model of the retention process for this thesis, based on the literature review, was formulated and is shown in Figure 2. Most models of retention intentions have included many of the same variables, but they have differed in their categorization of those variables and in their posited causal order. The theoretical model used in this thesis is a function of four categories of explanatory variables: demographic (such as gender and race), tenure (such as pay grade), economic (such as probability of finding a good civilian job) and cognitive (such as satisfaction). The model used throughout the analysis is presented here in ge neral form.

Intention of Retention $=f($ Demographic, Tenure, Economic, Cognitive $)$

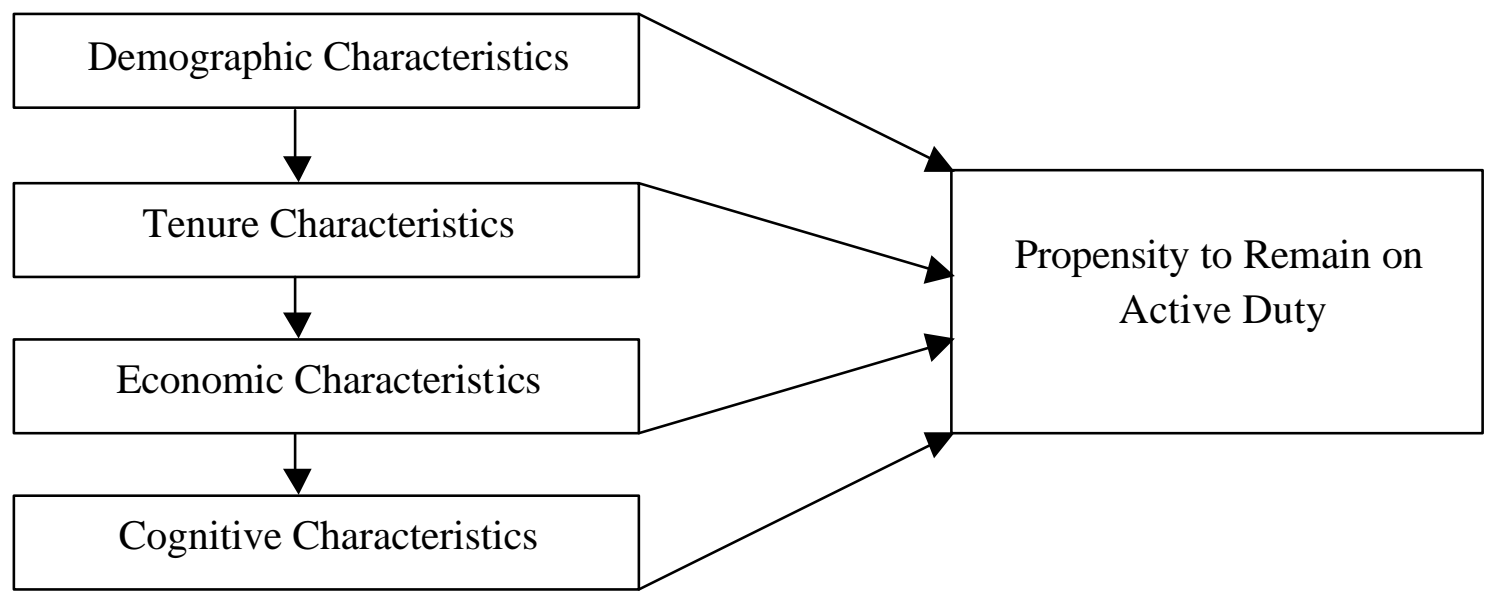

Figure 2. The Hypothesized Retention Model 
THIS PAGE INTENTIONALLY LEFT BLANK 


\section{MODEL ESTIMATION}

\section{A. DEPENDENT VARIABLE AND MODEL SPECIFICATION}

An analysis of junior male Army officers' retention is based on the ability to define the critical factors affecting career decisions. Retention is defined as a male junior officer's decision to stay in the Army. Alternatively, the officer may choose to leave the service. Therefore, the retention outcome is modeled with a dichotomous dependent variable, which takes the value of " 1 " if the officer intends to stay and a value of "0" if the intention is to leave.

For the dependent variable of this thesis, stayers were identified as those survey respondents who answered the question of "How likely is it that you would choose to stay on active duty?" as "very likely or likely." Leavers are the respondents who replied as "unlikely or very unlikely." Undecided officers who replied as "neither likely nor unlikely" were omitted from the sample because their intentions are unclear and they could mislead the results and the recommendations for future policies.

While there are several estimation techniques that are appropriate for analyzing a dichotomous dependent variable, this thesis uses logistic regression due to the fact that the cumulative distribution of retention intention is often described well by S-shape patterns. (See Figure 3) 


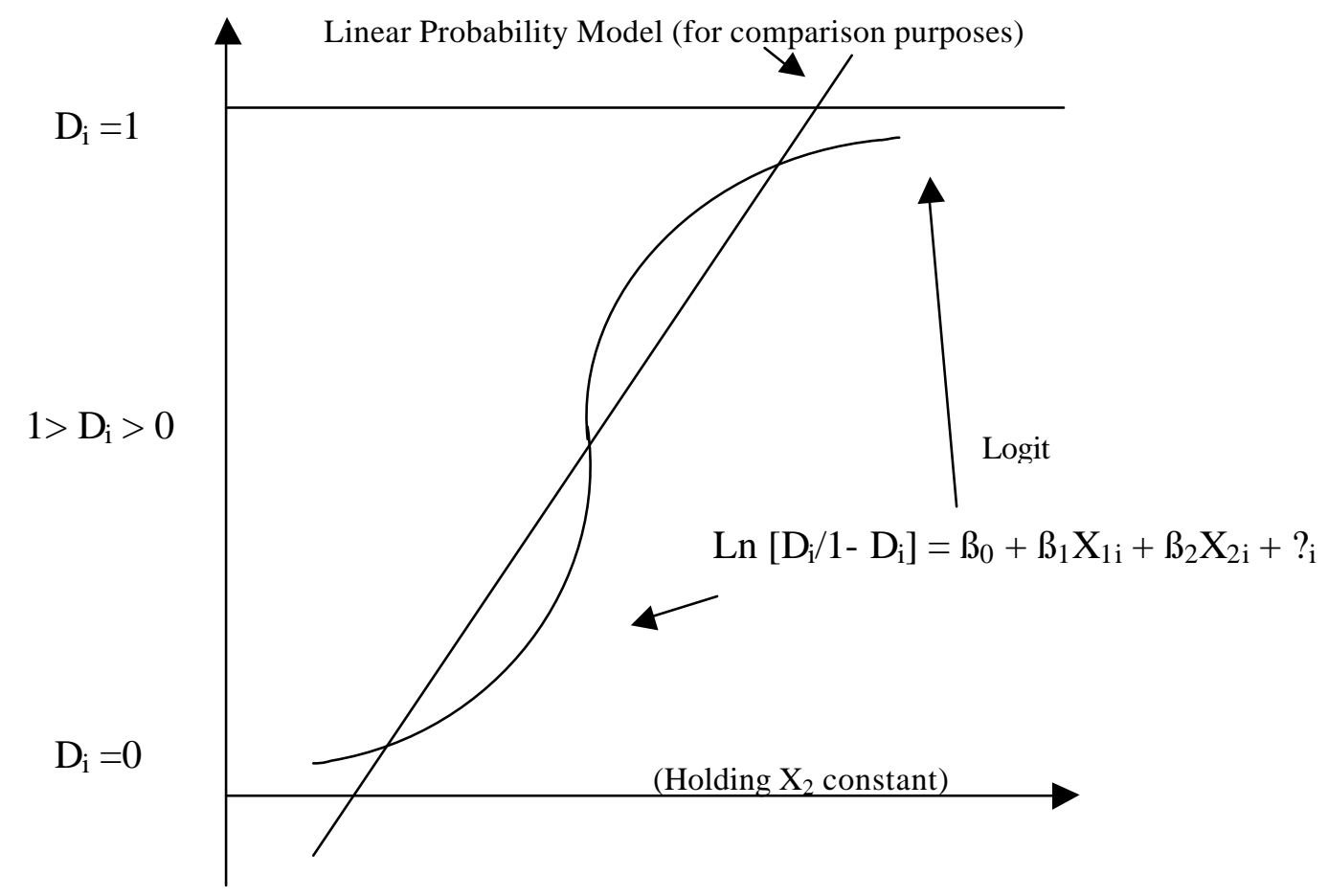

Figure 3. Comparison of Binomial Logit Model and Linear Probability Model, "From [Ref. 26]"

In nature, not all things are linear. The following explains some problems in using the Linear Probability model (LPM):

1. The error term is not normally distributed.

2. The error term is inherently heteroskedastic.

3. $R^{2}$ (adjusted coefficient of determination) is not an accurate measure of overall fit.

4. $D_{i}$ is not bounded by 0 and 1. [Ref. 26]

The logit model uses the maximum likelihood estimating technique that is especially useful for equations that are nonlinear in the coefficients. The maximum likelihood estimation is inherently different from the Ordinary Least Square (OLS) technique in that it chooses coefficient estimates that maximize the likelihood of the 
sample data set being observed. [Ref. 26] Also, the logit model is consistent, unbiased and has minimum variance for large samples. For these reasons, the logit model was selected to evaluate the relationships between a set of explanatory variables and a binary choice dependent variable for this thesis.

The cumulative logistic function for the logistic regression model is as follows:

$$
\left.P_{i} \text { (staying in the military }\right)=1 / 1+e^{-\left(X_{0}+B X+e\right.}+e_{i}[R e f .26]
$$

$P_{i}$ is the probability that a junior male Army officer will stay in the military. The "e" is the base of the natural algorithm. The $\mathrm{X}$ is the vector of $\mathrm{X}_{\mathrm{i}} \mathrm{s}$, the values of the explanatory variables, for individual $\mathrm{i} ; \beta$ is the vector of $\beta_{\mathrm{j}} \mathrm{s}$, the parameter values of the model; and $\mathrm{e}_{\mathrm{i}}$ is the $\mathrm{i}^{\text {th }}$ stochastic error term.

\section{B. EXPLANATORY VARIABLE DEFINITIONS AND HYPOTHESIZED RELATIONSHIPS}

Independent variables that were expected to affect the retention intention were chosen based on the literature review discussed in Chapter II. Individual variable definitions and their expected signs are discussed below:

\section{Demographic Characteristics}

\section{a. Race/ Ethnic Group}

Race/Ethnic group is coded as a set of dummy variables, categorized as Black, Hispanic, and Other (American Indian, Alaskan Native, and Asian/Pacific Islander). Black, Hispanic, and Other account for $4.85 \%, 3.53 \%$, and $8.97 \%$ of the data sample, respectively. Since Black and Hispanic have similar retention behavior and small size in this data set, their observations are combined to form a grouped dichotomous Race/Ethnicity variable. Membership in these groups was hypothesized to have a positive relationship with the retention intention relative to the category of white. This was based on the assumption that minorities have traditionally experienced higher civilian unemployment rates than whites, and thus have fewer civilian employment alternatives. Previous studies have also concluded that minorities are more likely to be retained than whites. [Ref. 23] 


\section{b. Family Status}

The family status of army officer is coded as a set of dummy variables: "single with no dependent" (SND), "single with dependent" (SWD), "married with no dependent" (MND), and "married with dependent" (MWD). However, SWD is omitted from the data set because of its small size (1\%). It is expected that MND and MWD are more likely to stay in the military than SND, the base case, because the opportunity costs associated with leaving active duty and finding employment with similar pay and benefits would be greater for those officers supporting their dependents.

\section{Tenure Characteristics}

\section{a. Military Rank (Pay Grade)}

The rank of each junior Army officer at the time of the survey is coded as a dummy variable for each rank; $\mathrm{O} 1, \mathrm{O} 2$, and $\mathrm{O} 3$, with $\mathrm{O} 1$ as the base case. $\mathrm{O} 1, \mathrm{O} 2$, and O3 comprise $17.65 \%, 55.59 \%$, and $26.76 \%$ of the data sample, respectively. Human capital theory suggests that as an individual experiences wage increases (a function of rank in the military) he or she is less likely to quit the current job because quitting becomes more costly (in terms of lost pay) associated with job changes and longer periods over which to recoup those losses. [Ref. 13] This theory might not fit the military for two reasons. Firstly, for senior officers, the more experience you have in the military, the more you enhance your civilian marketability. The civilian sector seeks experienced military personnel for their managerial job vacancies because of experienced officers' high leadership and management skills. Secondly, O1 officers are within their first two years of service and they have not yet experienced military life. Their retention intentions are not based upon their military life experience but mostly on their assumptions about military life. Thus, it is natural to expect higher retention intentions from an O1 than an $\mathrm{O} 2$ or an $\mathrm{O} 3$. As a result, the sign of military rank is hypothesized as uncertain because of these two offsetting tendencies. 


\section{b. Military Occupational Specialty}

The Military Occupational Specialties (MOS) are categorized as COMBAT, COMBATSUPPORT, and COMBATSERVICESUPPORT group. COMBAT represents tactical operation officers such as infantry, armor and artillery. COMBATSUPPORT includes officers from intelligence, engineering and maintenance, and health care. And COMBATSERVICESUPPORT contains officers from supply and procurement, administration service and scientific research. Since the majority of the survey respondents (51.19\%) are in the COMBAT group category, it serves as the base case.

It was expected that officers serving in the COMBATSUPPORT and COMBATSERVICESUPPORT group would be less likely to remain on active duty than the COMBAT group because the skills acquired in these MOS groups are more easily transferable to the civilian marketplace.

\section{c. Life Expectations (LIFEXP)}

The variable LIFEXP was generated from a survey question that measures the degree to which life in the military is what the member expected. Officers were asked to respond to the question, "In general, has your life been better or worse than you expected when you first entered the military?" response values range from one, indicating "much worse" to a value of five, indicating "much better." It is estimated that the more an officer's expectations about military life are met, the more likely he is to stay in the military.

\section{d. Matched Military Occupation (MATCHOCC)}

The variable MATCHOCC was generated from the survey question that asked officers, "Did you receive the military occupation of your choice?" It is hypothesized that if an officer receives his choice of military occupation or a related one, he would be more likely to stay in the military based on the assumption that he is satisfied with his occupation. 


\section{e. Remaining Time in Initial Obligated Service (RTIME)}

As discussed in Chapter III, officers have a contractual period of service required by a particular commissioning program plus any further obligation incurred due to some form of follow-on training (such as flight school). Response values range from one, indicating " 3 years or more" to a value of six, indicating "less than 3 months." It is estimated that the less time an officer has in initial obligated service, the more he would be concerned about his future and the more he would like to stay in the military due to experience in this occupation. The correlation of pay grade (coded 1,2, and 3 for $\mathrm{O} 1, \mathrm{O} 2$, and O3, respectively) with RTIME is -0.1761 .

\section{Economic Characteristics}

\section{a. Probability of Finding a Good Civilian Job (PROBJOB)}

Studies by economists and psychologists alike have found that the perceived chance of finding an alternative job affects quit behavior. [Ref. 13] This variable measures the officer's impression of his likelihood of finding a better job in the civilian sector if he leaves the job now. This variable ranges from a one "strongly disagree" to five "strongly agree." As the perceived chance of finding a better civilian job rises, retention intention is likely to fall. Therefore, a negative relationship with retention intention is hypothesized for this variable.

\section{b. $\quad$ Transferability of Military Experience and Training to Civilian} Job (CIVTRANS)

The variable CIVTRANS was generated from the survey question about the degree to which military experience and training can be directly transferred to a civilian job. Response values range from one, "Strongly disagree" to a value of five, "Strongly agree." It is expected that those officers who think that their experience and training are transferable would be more likely to plan to leave the military.

\section{Cognitive Characteristics and Factor Analysis}

Due to the large number of candidate cognitive/job satisfaction variables (see Table 9), factor analysis was used to reduce the number of variables that are measuring similar attributes among related groups of variables. 
Factor analysis is a technique used to determine whether or not underlying patterns of relationships exist among a group of variables, so that the data may be reduced to a smaller set of a common factors or components that may be taken as source variables accounting for the observed interrelations in the data. [Ref. 27] The number of factors actually chosen for each category of questions is based on:

- those factors with Eigenvalues greater than or equal to one,

- those factors that seemed to represent logical groups of variables. [Ref. 30]

In an effort to reduce the number of independent variables in the model, the nineteen "satisfaction with military life" variables were combined and reduced to four principal components. Once the factors were extracted, they were rotated using the varimax rotation technique to derive more easily interpretable variables. Table 11 displays the factors and the related satisfaction variables.

Table 11. Factor Analysis of Job Satisfaction Variables

\begin{tabular}{|l|c|c|c|c|}
\hline \multicolumn{1}{|c|}{$\begin{array}{c}\text { Component Factors and Related } \\
\text { Satisfaction Variables }\end{array}$} & \multicolumn{3}{|c|}{ FACTOR LOADINGS } \\
\hline \hline Satisfaction with Military Intrinsic Values & \multicolumn{3}{|l|}{} \\
\hline \hline Unit's Morale & $\mathbf{0 . 7 0 5}$ & 0.058 & 0.152 & 0.013 \\
\hline \hline Enjoyment from Job & $\mathbf{0 . 6 3 0}$ & 0.262 & 0.159 & 0.134 \\
\hline \hline Personal Workload & $\mathbf{0 . 6 2 2}$ & 0.042 & 0.287 & 0.096 \\
\hline \hline Quality of Leadership & $\mathbf{0 . 4 8 8}$ & 0.339 & 0.116 & 0.116 \\
\hline \hline Personal/Family Time & $\mathbf{0 . 4 8 6}$ & 0.015 & 0.387 & 0.134 \\
\hline Military Values & $\mathbf{0 . 4 3 5}$ & 0.334 & 0.095 & 0.125 \\
\hline Level of Manning in Unit & $\mathbf{0 . 4 2 8}$ & -0.037 & 0.222 & 0.131 \\
\hline Type of Assignments & $\mathbf{0 . 4 0 5}$ & 0.356 & 0.240 & 0.122 \\
\hline \hline \multicolumn{1}{|c|}{ Satisfaction with Military Career } & & & \\
\hline Advancement Opportunities & & & & \\
\hline Chances of Future Advancement & 0.091 & $\mathbf{0 . 7 6 6}$ & 0.169 & 0.068 \\
\hline Pace of Promotions & 0.053 & $\mathbf{0 . 6 2 5}$ & 0.294 & 0.073 \\
\hline \hline Training and Professional Development & 0.427 & $\mathbf{0 . 4 5 1}$ & 0.115 & 0.161 \\
\hline Job Security & 0.062 & $\mathbf{0 . 4 0 0}$ & 0.031 & 0.076 \\
\hline
\end{tabular}


Table 11. Factor Analysis of Job Satisfaction Variables (Continued)

\begin{tabular}{|l|c|c|c|c|}
\hline \multicolumn{1}{|c|}{$\begin{array}{c}\text { Component Factors and Related } \\
\text { Satisfaction Variables }\end{array}$} & \multicolumn{3}{c|}{ FACTOR LOADINGS } \\
\hline $\begin{array}{c}\text { Satisfaction with Military Job Deployment } \\
\text { and Economic Life }\end{array}$ & & & \\
\hline Other Military Duties & 0.246 & 0.114 & $\mathbf{0 . 6 2 3}$ & 0.040 \\
\hline \hline Deployments & 0.248 & 0.125 & $\mathbf{0 . 5 8 4}$ & 0.050 \\
\hline Basic Pay & 0.085 & 0.229 & $\mathbf{0 . 3 4 1}$ & 0.122 \\
\hline Frequency of PCS Moves & 0.157 & 0.212 & $\mathbf{0 . 3 2 4}$ & 0.103 \\
\hline Retirement Pay & 0.144 & 0.125 & $\mathbf{0 . 3 1 7}$ & 0.241 \\
\hline \hline Satisfaction with Military Health Services & & & & \\
\hline \hline Medical Care & 0.203 & 0.139 & 0.150 & $\mathbf{0 . 7 9 7}$ \\
\hline \hline Dental Care & 0.116 & 0.157 & 0.124 & $\mathbf{0 . 7 7 3}$ \\
\hline
\end{tabular}

\section{a. $\quad$ Satisfaction with Military Intrinsic Values (Factor1)}

The variables that "loaded" most heavily on FACTOR 1 were responses to those survey questions that measured the officer's satisfaction with various intrinsic values such as unit's morale, personal workload, enjoyment from job, personal and family time, quality of leadership, level of manning in unit, military values, and type of assignments. It was hypothesized that an increase in satisfaction with military intrinsic values would lead to an increased likelihood of retention.

\section{b. Satisfaction with Military Career Advancement Opportunities (Factor2)}

Satisfaction variables such as job security, advancement opportunities, pace of promotion, and training form FACTOR2. It is estimated that one who is more satisfied with career advancement opportunities will more likely stay in the military.

\section{c. Satisfaction with Military Job Deployment and Economic Life (Factor3)}

The variables that weighed most heavily on this category were satisfaction with frequency of PCS moves (Permanent Change of Station), other military duties, 
deployments, basic pay and retirement pay. It is estimated that the more the officer is satisfied with this area, the greater the chances he will remain in the military.

\section{d. Satisfaction with Military Health Services (Factor4)}

Factor4 consisted of satisfaction variables with medical and dental care. An officer's satisfaction with military health services is hypothesized to have a positive relationship with retention intention.

Table 12 provides a summary of the model explanatory variables and their hypothesized relationship with retention intention.

Table 12. Explanatory Variable and Expected Signs

\begin{tabular}{|c|c|}
\hline Variable & Expected Sign \\
\hline \multicolumn{2}{|l|}{ Demographic Characteristics } \\
\hline Race/Ethnic Group (Black/Hispanic, and Other) & + (compared to White) \\
\hline Family Status (MND, MWD) & $+($ compared to SND) \\
\hline \multicolumn{2}{|l|}{ Economic Characteristics } \\
\hline $\begin{array}{l}\text { Probability of Finding a Good Civilian Job } \\
\text { (PROBJOB) }\end{array}$ & - \\
\hline $\begin{array}{l}\text { Transferability of Military Experience and Training to } \\
\text { Civilian Job (CIVTRANS) }\end{array}$ & - \\
\hline \multicolumn{2}{|l|}{ Tenure Characteristics } \\
\hline Military Rank (O2, O3) & Uncertain (compared to $\mathrm{O} 1$ ) \\
\hline $\begin{array}{l}\text { Military Occupational Specialty (Combatsupport, } \\
\text { Combatservicesupport) }\end{array}$ & - (compared to Combat) \\
\hline Life Expectations (LIFEXP) & + \\
\hline Matched Military Occupation (MATCHOCC) & + \\
\hline Remaining Time in Initial Obligated Service (RTIME) & + \\
\hline \multicolumn{2}{|l|}{ Cognitive Characteristics } \\
\hline Satisfaction with Military Intrinsic Values (FACTOR1) & + \\
\hline $\begin{array}{l}\text { Satisfaction with Military Career Advancement } \\
\text { Opportunities (FACTOR2) }\end{array}$ & + \\
\hline $\begin{array}{l}\text { Satisfaction with Military Job Deployment and } \\
\text { Economic Life (FACTOR3) }\end{array}$ & + \\
\hline Satisfaction with Military Health Services (FACTOR1) & + \\
\hline
\end{tabular}




\section{MODEL RESULTS}

\section{Discussion of Estimated Coefficients}

\section{a. Are the Hypotheses Verified?}

The signs of the coefficients of all the explanatory variables, except for FACTOR4, are in my hypothesized direction. Since FACTOR4 is not significantly different from zero, it does not have impact on explaining the retention intention. Also, it can be concluded that the model equation is supported by the sound theory and the explanatory variables are chosen correctly. Table 13 displays the parameter estimates and associated probability values for the model.

Table 13. Logistic Regression Results for Junior Male Army Officers

\begin{tabular}{|c|c|c|}
\hline Variable & Parameter Estimate & Probability Value \\
\hline $\mathrm{O} 2$ & -0.2917 & 0.3439 \\
\hline O3** & -0.9107 & 0.0106 \\
\hline BLACK/ HISP & 0.1385 & 0.7139 \\
\hline OTHR* & 0.6977 & 0.0582 \\
\hline MWD** & 0.7129 & 0.0167 \\
\hline MND & 0.1042 & 0.6757 \\
\hline RTIME & 0.0288 & 0.8371 \\
\hline COMBATSUPPORT & -0.0618 & 0.8179 \\
\hline COMBATSERVICESUPPORT & -0.3777 & 0.2251 \\
\hline CIVTRANS & -0.0898 & 0.3945 \\
\hline PROBJOB $* * *$ & -0.5962 & $<.0001$ \\
\hline LIFEXP*** & 0.3951 & 0.0016 \\
\hline MATCHOCC & -0.0625 & 0.8037 \\
\hline FACTOR1*** & 0.9284 & $<.0001$ \\
\hline FACTOR2 $* * *$ & 0.5038 & 0.0004 \\
\hline FACTOR3 $3 * * *$ & 0.5589 & 0.0002 \\
\hline FACTOR4 & -0.0897 & 0.4721 \\
\hline
\end{tabular}




\section{b. Interpretation of the Meaning Significance and Magnitude of the Estimated Coefficients}

PROBJOB, LIFEXP, FACTOR1, FACTOR2, and FACTOR3 are all significant at the one percent significance level, while O3 and MWD are significant at the five percent significance level. OTHR is significant at the ten percent significance level. The rest of the explanatory variables are not significant at any of the usual level of significance. Significance and magnitude of estimated coefficients can be seen in Table 13. The binomial logit model was used to analyze the retention intention of junior male Army officers in pay grades $\mathrm{O} 1$ to $\mathrm{O} 3$. The behavioral assumption underlying this retention theory is that an officer has preferences between two alternatives: stay or leave. The logistic regression model relates the participation decision of the ith officer Yi to a "k" dimensioned vector of the individual characteristics of the Army officer. The relative contributions of the individual determinants of retention may be calculated in this nonlinear multivariate model by calculating the partial effects of each variable. The estimated logistic regression coefficients do not provide direct interpretation due to the non-linear nature of the coefficients. [Ref. 11] In logit regression, the change in $Y$ from one unit change in $X_{1}$ depends not only on $\beta 1$ but also the values of $X_{2}, X_{3}$ and the other explanatory variables.

The partial effects of explanatory variables on the dependent variable is calculated by measuring the impact of a one-unit change in each independent variable on the retention probability of a referent junior male Army officer. Using the mean value for the continuous variables and zero for the dummy variables, the referent or "base case" male junior Army officer in this sample is single without dependents, white, combatant in pay grade $\mathrm{O} 1$ with "7 months to less than 1 year" initial obligated service. He believes that he could easily find a good civilian job, and he disagrees that his experience and military training are transferable to civilian job. He thinks that life has been about what he expected when he first entered the military, and he received the military occupation of his choice. Values used for his level of satisfaction with military intrinsic values, military career advancement opportunities, military job deployment and economic life, and military health services were all at the mean levels for the sample. Table 14 summarizes 
the characteristics of the "base case" junior male Army officer. The meanings of variables in this table are defined in Section B of this chapter.

Table 14. Characteristics of the Base Case Individual

\begin{tabular}{|l|l|}
\hline \multicolumn{1}{|c|}{ Variable } & \multicolumn{1}{|c|}{ Base Case } \\
\hline \hline $\begin{array}{l}\text { Race/Ethnic Group (White, Black/Hispanic, and } \\
\text { Other) }\end{array}$ & White \\
\hline \hline Family Status (SND, MND, and MWD) & Single with no dependents \\
\hline Military Rank (O1, O2, and O3) & O1 \\
\hline $\begin{array}{l}\text { Military Occupational Specialty (Combat, } \\
\text { Combatsupport, and Combatservicesupport) }\end{array}$ & Combat \\
\hline \hline Life Expectations (LIFEXP) & About as expected \\
\hline \hline Matched Military Occupation (MATCHOCC) & Yes \\
\hline $\begin{array}{l}\text { Remaining Time in Initial Obligated Service } \\
\text { RTIME) }\end{array}$ & Agree \\
\hline $\begin{array}{l}\text { Probability of Finding a Good Civilian Job } \\
\text { (PROBJOB) }\end{array}$ & Disagree \\
\hline $\begin{array}{l}\text { Transferability of Military Experience and } \\
\text { Training to Civilian Job (CIVTRANS) }\end{array}$ & \\
\hline
\end{tabular}

\section{c. Interpretation of the Partial Effects}

The calculated partial effects of the logistic regression model are presented in Table 15.

Table 15. Partial Effects of Significant Explanatory Variables

\begin{tabular}{|l|c|}
\hline \multicolumn{1}{|c|}{ Variable } & Partial Effects \\
\hline \hline $\mathrm{O}^{*} *$ & -0.20640 \\
\hline $\mathrm{OTHR}^{*}$ & 0.17074 \\
\hline MWD $* *$ & 0.17423 \\
\hline \hline PROBJOB $* * *$ \\
\hline $\begin{array}{l}* * *=\text { Significant at one percent; } \\
* \\
=\text { Significant at ten percent. }\end{array}$ \\
\hline
\end{tabular}


Table 15. Partial Effects of Significant Explanatory Variables (Continued)

\begin{tabular}{|l|c|}
\hline \multicolumn{1}{|c|}{ Variable } & Partial Effects \\
\hline \hline LIFEXP*** & 0.09835 \\
\hline FACTOR1 $* * *$ & 0.22216 \\
\hline \hline FACTOR2 $* * *$ & 0.12486 \\
\hline \hline FACTOR3 $* * *$ & 0.13808 \\
\hline$* * *=$ Significant at one percent; $* *=$ Significant at five percent; \\
$*$ = Significant at ten percent. \\
\hline
\end{tabular}

Interpretation of the partial effects is as follows:

$\mathbf{0 3}$

The military rank variable, O3, is significant at the five percent significance level and is negatively signed. An O3 male Army officer has $20.6 \%$ less retention intention than an $\mathrm{O} 1$ male Army officer, ceteris paribus.

\section{OTHR}

The "other race" variable is significant at the ten percent significance level and it is positively signed. An Army officer of American Indian, Alaskan Native, or Asian/Pacific Islander origin has a 17\% higher retention intention than a white male Army officer, ceteris paribus.

\section{MWD}

The variable, married with dependents, is significant at the five percent significance level and is positively signed. A married junior male Army officer with dependents has a $17.4 \%$ higher retention intention than a single officer with no dependents, ceteris paribus.

\section{PROBJOB}

The probability of a finding a good civilian job variable is significant at the one percent significance level and is negatively signed. A one-unit increase in the probability of finding a good civilian job, given the base characteristics, yields a $14.1 \%$ decrease in the retention intention for male Army officers, ceteris paribus. 


\section{LIFEXP}

Officers' expectation for life when they first entered the military is significant at the one percent significance level and is positively signed. A one-unit increase in the expectations of male Army officers for military life results in $9.8 \%$ increase in intention to continue the military career, ceteris paribus.

\section{FACTOR1, FACTOR2, FACTOR3}

Three of the factor analysis variables, satisfaction with military intrinsic values, military career advancement opportunities, and military deployment and economic life are all significant at the one percent significance level and are positively signed. A one standard deviation increase from the average component score for these factors results in a $22.2 \%, 12.5 \%$, and $13.8 \%$ increase in retention intentions of Army officers, respectively.

\section{GOODNESS OF FIT}

The ultimate goal in any multivariate regression model is to find explanatory variables that are theoretically sound and relevant for meaningful policy interpretation. In this model, seven of the seventeen variables have a significant impact upon retention.

First, in order to measure the goodness-of-fit, a Global Null Hypothesis was tested. The test $(-2 \log \mathrm{L})$ has a Chi-Square distribution with the null hypothesis that all regression coefficients in the model are zero. The junior male Army officer retention model produced a -2 Log L Chi-Square score of 182.7976 with 17 degrees of freedom and a probability value of $<0.0001$. Based on this, the null hypothesis that the coefficients of all of the explanatory variables in the model are zero was rejected. It is concluded that the explanatory variables as a group are statistically significant in explaining the dependent variable.

Another measure for goodness-of-fit of logistic regression models is $R_{p}^{2}$ (the percentage of correctly predicted observations in the sample). The model's $\mathrm{R}_{\mathrm{p}}^{2}$ (Number of observations predicted correctly/ Total Observations) is 72.7 with the probability cutpoint of 0.58 . Thus, it can be concluded that $72.7 \%$ of the observations in the data set are 
classified correctly as stayers or leavers when using this model. The generalized coefficients of determination for general binomial models, $\mathrm{R}^{2}$ and $M a x \mathrm{R}^{2}$ [Ref. 5], are 0.28 and 0.38 , respectively for this model. These are relatively low values for these statistics, but typical for models of individual level retention.

The degree of multicollinearity present is another goodness-of-fit measure applied to multivariate regression models. Multicollinearity exists when an explanatory variable is linearly related to one or more of the other explanatory variables. [Ref. 26] A sufficiently strong linear functional relationship between two or more explanatory variables can make the coefficient estimates unstable. In order to detect multicolllinearity in this model, simple correlation coefficients between the explanatory variable were examined. Pay grade, length of service, and age variables were found to be highly correlated. The year of service (YOS) variable has the correlation coefficient of 0.67 with the age variable (RAGE_M). Another measure of the severity of multicollinearity is the variance inflation factor (VIF). The variance inflation factor (VIF) is a method of detecting the severity of multicollinearity by looking at the extent to which a given explanatory variable can be explained by all other explanatory variables in the equation. [Ref. 26] The VIF of the age variable (2.070) was found to be greater than the VIF of the model (1.407). As a result of these tests, the age and length of service variables were omitted from the model and the pay grade variables were retained.

Furthermore, in order to reduce the number of collinear variables measuring similar satisfaction attributes among related groups of variables, factor analysis was used and nineteen "satisfaction with military life" variables were combined and reduced to four uncorrelated principal components (See cognitive characteristics and factor analysis for this procedure in Section B of this chapter). 
THIS PAGE INTENTIONALLY LEFT BLANK 


\section{QUADRANT ANALYSIS}

The purpose of "Quadrant Analysis" is to determine which employee satisfaction variables need improvement in order to raise an organization's overall level of job satisfaction. The analysis involves determining the importance of each employee satisfaction facet to overall job satisfaction and an organization's current performance in each facet. Two metrics are used for each employee satisfaction facet:

\section{Importance Metric}

A measure of the importance of each employee satisfaction variable (Pay, medical care, dental care, retirement, promotion, advancement, training, assignment, deployment, other duty, manning, morale, workload, personal time, leadership, military values, enjoyment) to overall military job satisfaction. These variable correlations with overall military job satisfaction are used to determine the degree to which each variable is related to overall job satisfaction. A value of " 0 " indicates no correlation, and a value of " 1 " indicates perfect correlation. Variables with correlations closer to "1" are considered to have higher importance. Table 16 displays the importance metric.

\section{Performance Metric}

This metric indicates how well the military performs in each facet of satisfaction with the military. For each of the 19 satisfaction variables, the percent of respondents who indicated satisfaction with that variable is determined. This performance metric is constructed by recoding responses as, "very satisfied and satisfied=1" and "dissatisfied and very dissatisfied $=0$." The closer the percent is to 100 , the better the military is performing. Table 16 displays the performance metric.

Before plotting the data in the graph, the plot was partitioned into quadrants. The initial placement of the lines to form the quadrants of equal size is somewhat arbitrary and should be thought of only as a starting place. The lines can be moved up or down, or left or right to include more or fewer items in each quadrant, as specific offices or

programs see appropriate. For this thesis, the cutting lines for performance and importance are $50 \%$ and $40 \%$, respectively. 
Table 16. Quadrant Analysis Variables

\begin{tabular}{|c|c|c|c|c|c|}
\hline \multirow{2}{*}{ Satisfaction Variable } & \multirow{2}{*}{ Labels } & \multicolumn{2}{|c|}{ Frequency } & \multirow{2}{*}{ Performance } & \multirow{2}{*}{ Importance } \\
\hline & & Satisfied & Dissatisfied & & \\
\hline PAY & $\mathbf{P}$ & 241 & 306 & 44.06 & 0.28 \\
\hline MEDICARE & $\mathbf{M}$ & 251 & 296 & 45.89 & 0.31 \\
\hline DENTAL CARE & D & 288 & 259 & 52.65 & 0.23 \\
\hline RETIREMENT & $\mathbf{R}$ & 102 & 445 & 18.65 & 0.24 \\
\hline PROMOTION & PR & 328 & 219 & 59.96 & 0.27 \\
\hline ADVANCEMENT & $\mathbf{A}$ & 367 & 180 & 67.09 & 0.32 \\
\hline TRAINING & $\mathbf{T}$ & 288 & 259 & 52.65 & 0.40 \\
\hline ASSIGNMENT & $\mathbf{A S}$ & 309 & 238 & 56.49 & 0.46 \\
\hline DEPLOYMENT & DE & 157 & 390 & 28.70 & 0.37 \\
\hline OTHER DUTY & $\mathbf{O}$ & 134 & 413 & 24.50 & 0.36 \\
\hline MANNING & MA & 83 & 464 & 15.17 & 0.28 \\
\hline MORALE & MO & 204 & 343 & 37.29 & 0.39 \\
\hline WORKLOAD & $\mathbf{W}$ & 205 & 342 & 37.48 & 0.45 \\
\hline PERSONAL TIME & PE & 140 & 407 & 25.59 & 0.44 \\
\hline LEADERSHIP & $\mathbf{L}$ & 246 & 301 & 44.97 & 0.40 \\
\hline MILITARY VALUES & MV & 316 & 231 & 57.77 & 0.41 \\
\hline ENJOYMENT & $\mathbf{E}$ & 260 & 287 & 47.53 & 0.58 \\
\hline PCS & PC & 219 & 328 & 40.04 & 0.27 \\
\hline SECURITY & $\mathbf{S}$ & 408 & 139 & 74.59 & 0.16 \\
\hline $\begin{array}{l}\text { PERFORMANCE: Perc } \\
\text { IMPORTANCE : Cor }\end{array}$ & se of & fied $m$ & ers & , & \\
\hline
\end{tabular}

$\mathrm{n}=547$

Quadrant analysis results are presented in Figure 5. The interpretation of the results follows: 


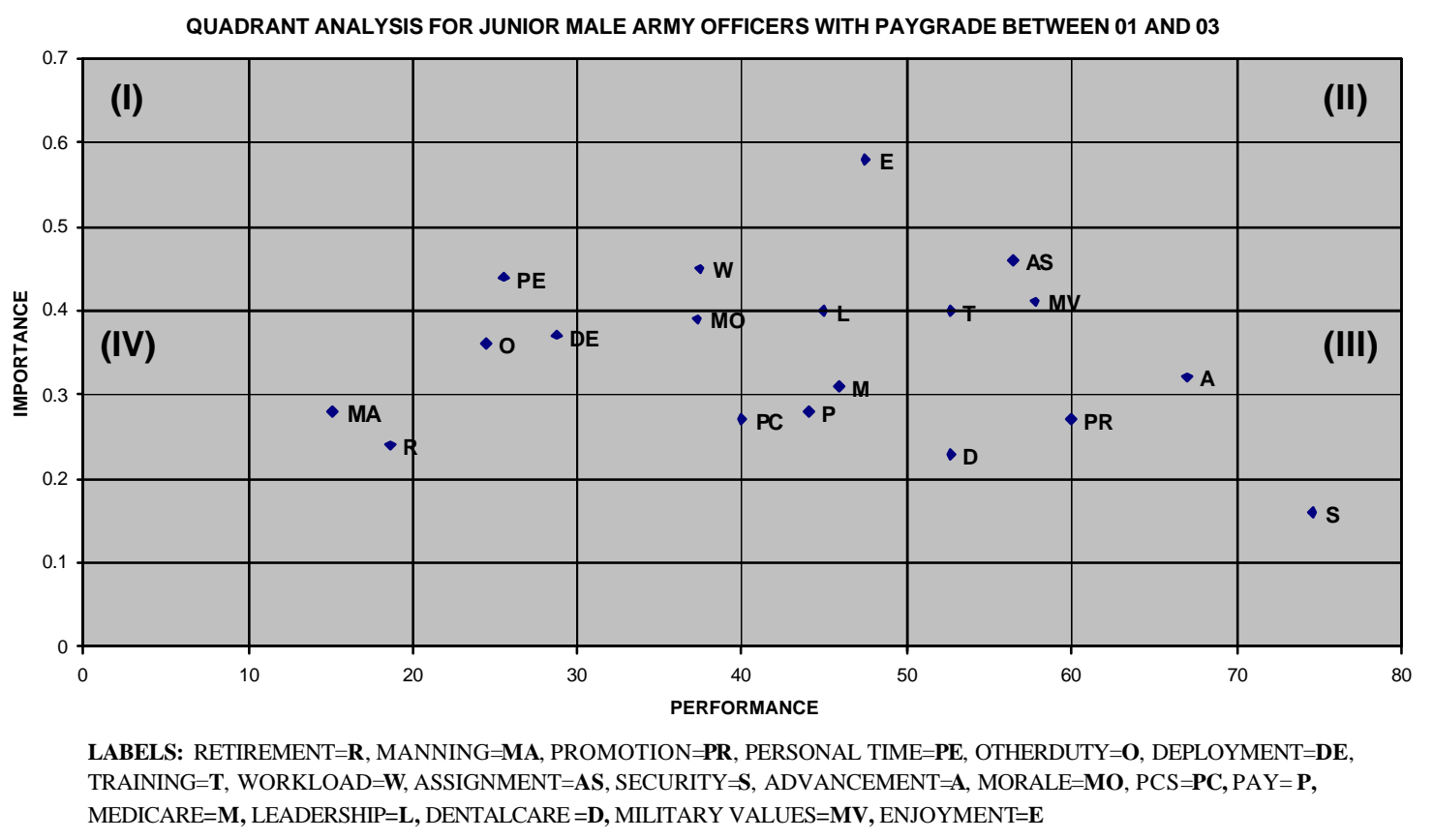

Figure 4. Quadrant Analysis for Junior Army Male Officers

\section{a. QUADRANT I: Critical Improvement Areas (high importance, low performance)}

In the workload, personal time, enjoyment satisfaction areas, the military is not performing as well as it could be, but these have a considerable impact on overall satisfaction with military life. These areas are excellent candidates for immediate attention.

\section{b. QUADRANT II: Maintain Current Level Areas (high importance, high performance)}

In the assignment, military values, and training satisfaction areas, the military is performing well and these are important to overall military job satisfaction. The military should continue current practices and allocate resources for these items so that member satisfaction does not decline and negatively affect overall military job satisfaction. 


\section{c. QUADRANT III: Lower Return to Improvement (low importance, high performance)}

In the dental care, promotion, security, and advancement areas, the military is performing well, but, while important to overall military job satisfaction, these facets do not have as great an impact as some other variables. Generally, additional resources should be devoted to these areas, only if these are low cost improvements.

d. QUADRANT IV: Lower Return to Investment (low importance, low performance)

In the manning, other duty, retirement, deployment, morale, leadership, medical care, pay, and PCS areas, the military is not performing as well as it could, but these are also not considered to have a critical impact on overall job satisfaction. There is a lower return on the investment in these variables, but, given resources, improvement could be sought. 


\section{CONCLUSIONS AND RECOMMENDATIONS}

\section{A. CONCLUSIONS AND RECOMMENDATIONS}

This thesis investigates the factors that influence the retention intentions of 680

junior male Army officers who are serving within their initial obligated service. Data for this thesis were drawn from responses to the 1999 DoD Survey of Active Duty Personnel [Ref. 36] to estimate the models. The survey includes data on the retention intentions of service members. Past research has shown that a member's intention is a good predictor of retention behavior. Logistic regression analysis is used to identify demographic, tenure, economic and cognitive characteristics that significantly affect the intention to stay or to quit the military and to assess their relative importance. The SAS software package is used to analyze the data.

The model developed is successful in identifying several factors influencing the retention intentions of junior male Army officers. Eight of the seventeen variables included in the model have a significant impact upon retention. The factors found to influence officers' decision to remain on active duty include: among the demographic characteristics, family status and race; from the tenure characteristics, military rank (O3) and military life expectation; from economic characteristics, probability of finding a good civilian job, and from the cognitive characteristics, satisfaction with military intrinsic values, military career advancement opportunities, and military deployment and economic life.

These statistically significant explanatory variables can be valuable to Army manpower planners. For example, based on an analysis of model partial effects, a married male junior Army officer who has dependents is $17.4 \%$ more likely to stay in the military than is a single officer with no dependents, perhaps due to the greater opportunity costs associated with leaving the military and finding employment with similar pay and benefits for those officers supporting their dependents. Thus, it is recommended that the Army continue its emphasis on family-oriented programs. Improvements in areas such as care for dependents and family services not only impact the morale and readiness of its personnel but also influence retention. 
An Army officer of American Indian, Alaskan Native, or Asian/Pacific Islander origin has a $17 \%$ higher retention intention than a white male Army officer. This result suggests that, using retention as the only measure of effectiveness, more advertising dollars might be spent to recruit members of this group.

An O3 male Army officer is $20.6 \%$ less likely to remain in the military at the end of his obligated service than is current $\mathrm{O} 1$ officer. Experience in military makes these officers attractive to civilian sector and increases their marketability. However, O3s are also more valuable to Army than O1s because of their high supervising, management and training abilities over enlisted soldiers. These results dictate that the Army should put emphasis on career orientations of $\mathrm{O} 3 \mathrm{~s}$ rather than $\mathrm{O} 1 \mathrm{~s}$ who just signed their contracts and supposedly are content with military life.

Officers' expectations for life when they first entered the military are also shown to be a significant influence on intentions. This result indicates that recruiters and advertisers should display military life as it is, rather than making exaggerations and misleading young individuals with illusions. If the expectations of an individual are not met after entering the service, he is more likely to quit at the end of contracted service, incurring high training costs to the military. Demonstrating military life accurately to young potential military joiners may decrease the number of accessions, but the Army could retain more officers whose expectations are met. (9.8\% in this study)

The perception of external employment opportunities is also important and significant in the retention decision process for junior male Army officers. Officers who strongly agree that they can find a good civilian job are $14.1 \%$ less likely to remain on active duty. Although the Army has little or no control over the chance of finding a good civilian job alternative, policy maker should remain aware of how this factor affects retention, and how it can vary over time. However, using career counselors effectively for those people nearing their initial obligated service may have a positive effect on retention. The counselor could inform the officers about what they can realistically expect to earn in civilian jobs and then emphasize the advantages the Army can offer over civilian opportunities.

Satisfaction with military intrinsic values, military career advancement opportunities, and military job deployment and economic life yield 22.2\%, $12.5 \%$, and 
13.8\% increase in retention likelihood of junior male Army officers, respectively. Although these component factors give an idea about how these satisfaction variables affect the retention intentions of male Army officers. Separating the effects of individual facets of satisfaction is difficult. A quadrant analysis of the satisfaction variables indicates target areas for improvement in order to raise the military's overall level of job satisfaction. It is concluded that the areas of strength for the Army are assignment, military values, and training. In these satisfaction areas, the military is performing well and these are important to overall military job satisfaction. The workload, personal time, enjoyment satisfaction areas are problematic areas of the Army and need immediate attention. Improvements in the manning, other duty, retirement, deployment, morale, leadership, medical care, pay, and PCS areas are not considered to have a substantial impact on overall job satisfaction due to the lower return on investment in these variables.

Finally, the Army should not expect additional resources devoted to the dental care, promotion, security, and advancement areas to have as great an impact as they would if expended on other areas.

\section{B. FUTURE RESEARCH}

The inadequate number of women and minorities in this thesis made it difficult to analyze the factors that may have affected the retention intentions of these important

groups. Future surveys should attempt to assure sufficient sample size of these groups to conduct appropriate retention analysis.

This thesis used data from the 1999 DoD Survey of Active Duty Personnel to develop an econometric model to predict junior male Army officer retention intention. Due to the relatively recent fielding of the survey, this thesis was unable to test the validity of intention as a predictor of actual retention behavior. However, the results of the econometric model should be confirmed when actual turnover behavior information becomes available. Did the member stay or did he leave the military service? Does his actual behavior match his intentions? The validation of a model designed to predict retention intentions can only occur when follow-on data are used to compare the members' intentions with their actual behavior. 
This thesis also focused on the distinction among combat, combat support, and combat service support groups. These are very broad groupings. Future research should examine the differences in retention intentions by military occupational specialties (MOS).

Since O3s' retention intentions differ from O1s', future research should analyze O3s separately and identify the factors influencing the retention intentions of these officers who are of critical importance to the Army.

Army officer retention intentions are very sensitive to intrinsic, career advancement, and job deployment aspects. The more dissatisfied a junior male Army officer is with these aspects, the less likely he will be to stay in the Army. Further research should be done to define how effort should be expended in order to maintain each of these satisfaction variables at high levels. 


\section{APPENDIX}

1999 SURVEY of ACTIVE DUTY PERSONNEL
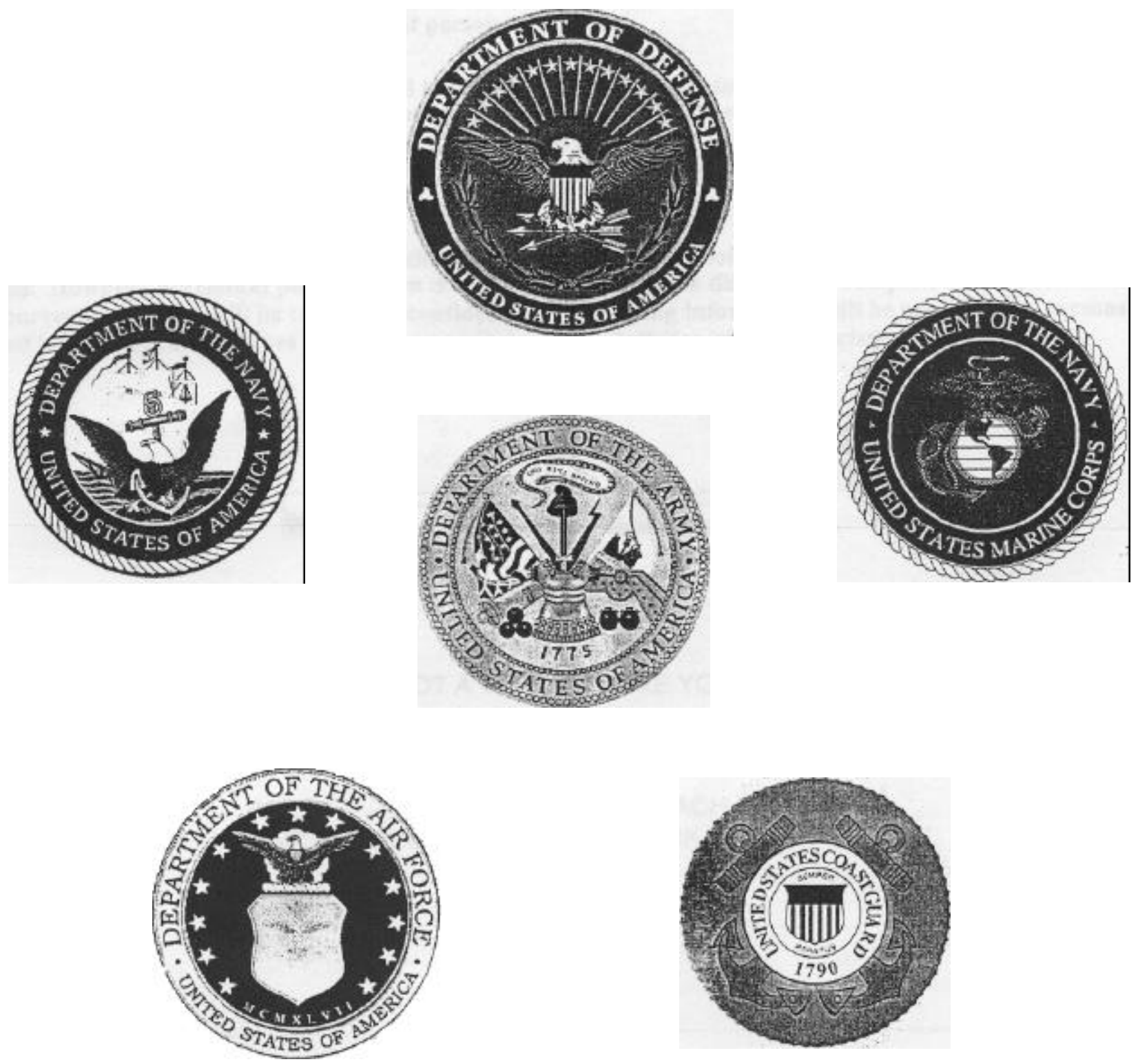

DMDC Survey No.99-0001

DEFENSE MANPOWER DATA CENTER ATTN:

SURVEY PROCESSING CENTER DATA RECOGNITION CORPORATION 5900 BAKER ROAD

MINNETONKA, MN 55345-5967 


\section{ASSIGNMENT INFORMATION}

M990/(C01320013)

1. During the past 12 months, hew many hours per week did you usually work?

1. $\mathrm{O} 40$ hours or less

2041.50 hours

3 O 51.60 hours

4. O $61-70$ hours

5. 071.80 hous

M9902

6. 081 hours or more

2. During yeur last full werkweek, how many hours did you work?

1. 040 hours or less

2. 041.50 hours

3 O 51.60 hours

4 O 61 -70 hours

5. $071-80$ hours

$6 \mathrm{O} 81$ hours or more

M9903AM9903P/Coding Note 36

3. When yeu have had to werk mere hours than usual during the past 12 months, what were the primary reasens? (MARK ALL THAT APPLY.)

A. ONot applicable

B OMission critical requirements

C. OMission preparation'training/maintenanoe

D.. O Tasked with additional duties (e.g, special projects)

E. O Unit was getting ready for deployment

E. OMarning not sufficient for worklasd (ie., not enough suthorizationshillets)

G. O Unit was under-manned (i.e., authorizationsibillets not filled)

H. OPart of unit was deployed

L. ODemanding supervisor

I.. O Problems involving subordinates

K.. O High worklosd

L.. O Poor plarning or lack of planning

M.. O Others were not carrying their workload

N. O Inspections and inspection preparation

Q. O Equipment failure and repairs

P ONone of the above

M9904* (O002R002)

4. Are you currently assigned to ship or shore duty?

1. O Ship

2. O Shore

60. ODves not apply, I do not have a ship/shore rotation

In this survey, "permanent duty station" is considered your permanent post, base, port, or other duty location, such as, a recruiting station.
M9g0s* (Comment)

5. Where is yeur permanent duty statien lecated?

1. O In ore of the 50 States or the District of Culumbia

2 O In American Samoa, Guam, U.S. Virgin Islands or Puerto Rico

3. OOverseas

Mggo6. I Coding Note 1

6. Are yeu currently on a deployment that will krep you away from home for at least 30 censecutive days?

1. OYes

2. O No $\rightarrow$ Go to Question 8 Mg906SK

M9907*

7. Where sre you currently deplesed?

1. O In ane of the 50 States or the District af Calumb ia

2. O In Amerion Samos, Guam, U.S. Virgin Islands or Puerto Rica

3. O Overseas

4. O Afloat at sea

Meg08.(O0]4(EO]4).

8. Where do you live at your permanent duty statien?

1. O Aboard ship

2. $\mathrm{O}$ Barracks/dorm (including BEQ or BOQ)

3. O Geographic bachelor's barracks

4 O Military family housing, on base

5. O Military family housing, off base

6. O Civilian housing that I own or pay mortgage on

2. O Military or civilian housing that I rert, off base

8. OOther

M9909A-Mp9091 (O015/E015)

9. How satisfied are you with the following

characteristics of your curreat residence and community at yeur permanest duty station? 5 :min: Very dissatisfied 4--.-Dissatisfied

3.:- Neither satisfied nor dissatisfied $2 \ldots$ Satisfied

a. Cost of residence --: Very satisfied

b. Quality and condition of 00000 residence

c. Amount of livable space in 00000 residence

d. Privacy of residence $\quad 00000$

e. Quality of housing in the $\mathrm{OOOOO}$ area where you live

f. Safety of the area where you 00000 live

g. Distance to workplace $\quad \mathrm{OOOOO}$

h. Distance to shopping areas $\quad 00000$

i. Distance to recreation areas $\mathrm{O} O \mathrm{O} O \mathrm{O}$ 
M9910A-M9910R/Coding Note 36

10. Why did you choose your current residence at your permanent duty station? (MARK ALL THAT

APPLY.)

A... O I had no choice in my residence

B... O Best value for the money

C... O Safety and security

D... O Close to workplace

E... O Close to base facilities, services or programs

F... O Spouse's choice

G... O Better schools

H... O Fewer rules

I... O Privacy

J... O Wanted to live in a specific area or community

K... O Available right away

L... O Military housing was unavailable

M... O Civilian housing was unavailable

N... O Better than available military housing (on base or off base)

O... O Better than available civilian housing

P.... O Wanted military neighbors

Q... O Wanted civilian neighbors

R.. O Other

M9911

11. If your cost to live in civilian or military housing at your permanent duty station were the same, where would you prefer to live?

1.. O Military housing, on base

2. O Military operated housing, off base

3. O Civilian housing

M9912(O018/E018)/Coding Note 2

12. During your active duty career, how many permanent changes of station (PCSs) have you made? (INCLUDE PCS FOR A REMOTE OR UNACCOMPANIED TOUR.)

61. O Does not apply, I have not yet received my first

1. 01 assignment $\rightarrow$ Go to Question 14 M9912SK

2. 02

$\begin{array}{lll}2 & 0 & 2 \\ 3 & 0 & 3\end{array}$

404

505

6.06
7.07
8.08
9.09
10. 010 or more

M9913A-M9913Z (O012/E012)

13. For your most recent $P C S$ move, were any of the following a problem? (ANSWER EVEN IF THIS IS YOUR FIRST ASSIGNMENT.)

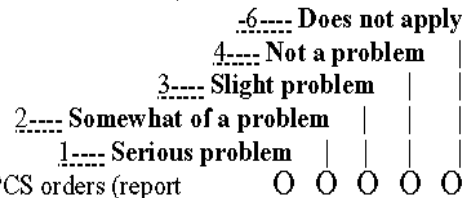

a. Change in PCS orders (report $\begin{array}{lllllllllllllll}0 & 0 & 0 & 0 & 0\end{array}$ date or destination)

b. Hours and location of offices $\mathrm{OOOOO}$ providing PCS assistance

c. Waiting for permanent housing $\mathrm{O} O \mathrm{O} O \mathrm{O}$ to become available

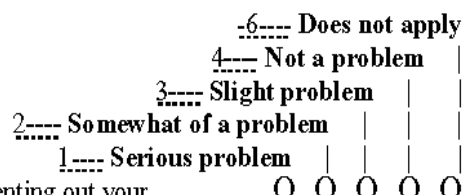

d. Selling or renting out your

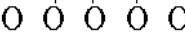
former residence

e. Purchasing or renting your

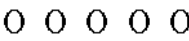
current residence

f. Amount of time to prepare for

$\mathrm{O} O \mathrm{O} O \mathrm{O} O$ move

g. Shipping/storing household

$\mathrm{O} O \mathrm{O} O \mathrm{O} O$ goods

h. TAD/TDY en route

00000

i. Temporary lodging expenses

00000

j. Costs related to security

$\mathrm{O} 0 \mathrm{O} O \mathrm{O}$ deposit(s)

k. Cost of moving pets

00000

1. Cost of moving vehicles

$\mathrm{O} O \mathrm{O} O \mathrm{O} O$

m. Costs of setting up new residence (e.g., curtains,

$\mathrm{O} O \mathrm{O} O \mathrm{O} O$ carpeting, painting).

n. Settling damage claims

00000

o. Non-reimbursed transportation costs incurred during the move

00000

p. Timeliness of reimbursements

00000

q. Accuracy of reimbursements

00000

r. Time off at destination to complete move

s. Change in cost of living

00000

t. Loss or decrease of spouse

O 0000 income

u. Spouse employment

00000

$\mathrm{O} O \mathrm{O} O \mathrm{O}$

v. Transferability of entitlements

$\mathrm{O} 0 \mathrm{OOO}$ (e.g., Supplemental Security Income)

w. Obtaining special education services

$\mathrm{x}$. Spouse/dependents changing schools

y. Transferability of college credits

00000

O 0000

z. Availability of childcare

O 0000

00000 
In this survey, the definition of "military duties" includes deployments, TADs/TDYs, training, military education, time at sea, and field exercisesialerts. M9914LCoding.Note. 3

14. In the past 12 manths, have you been away from your permaneat duty station evernight becauxe of yeur military duties?

1. O Yes

2. $\mathrm{ONo} \rightarrow$ Go to Question $19 \quad \mathrm{M} 99 \mathrm{~J} 4 \mathrm{SK}$ M9915

15. In the past 12 months, bow many separate times were you away from your permanent duty station for at least one night because of your military duties?
I. Ol-2 times
5. O9-10 times
2. O3-4 times
6. $011-12$ times
3 O 5-6 times
2. 013 times or more

4 O 7.8 times

M9916A-M9916 J*

16. During the past 12 menths, hew long were yeu away from your permanent duty station for the following military duties? (ADD UP ALL NIGHTS AWAY FROM YOUR PERMANENT DUTY STATION; ASSIGN EACH NIGHT TO ONLY ONE TYPE OF MILITARY DUTY,

6:- -10 menths to 12 menths 5 .... 3 months to less than 10 meaths 4 ten 5 menths to less than 7 nonths 3 -... 3 months to less than 5 menths 2 .-.. 1 menth to less than 3 menths d:-... Less than 1 month the.... None |

a. Peacebseping or other 0000000 contingency operation

b. Foreign bumanitarian 0000000 assistance mission

c. Unit training at combat 0000000 training centers

d Courher drugoperation 0000000

e. Domestic disastet or OOOOOOO civil emergency

f. Time at sea for scheduled deployments (other than for the above)

g. Other time at sea (other than for the above)

h. Joint training field exercisesialerts (other than for the above)
6-..- 10 months to 12 months 5 - 7 menths to less than 10 months $4=5$ months to less than 7 months $3-3$ menths to less than 5 months $2--1$ month to less than 3 months -.--Less thas 1 month $0-$ - Nene

i. Military education 0000000 (other than for the above)

j. Other TADs/TDYs 0000000 M9217* (0080.R081)

17. In the past 12 months, what was the total length of time you were away frem your permanent duty station because of your military duties? (ADD UP ALL NIGHTS AWAY FROM YOUR PERMANENT DUTY STATION.)

1. O Les thas 1 mont

2. 01 monith to less than 3 monthe

3.03 monthe bo lese than 5 mouthas

$\leq 05$ monthz to lese faso 7 montis

5. 07 monfas to les fasa 10 month

6. 010 monthe to 12 moatis

M9918A-M9928TCO078/F072X Codins Note 4

18. During the past 12 menths, have any of the fellowing been a cancern while you were away? (MARK ALL THAT APPLY.)

A. O Maraging expenes and bills

B... Household repairs, yard work, car maintenance

C. O Storage or security of personal belongings

D..OPet care

E..O Interruption of off duty education

E. O Loss of part-time job

G... Y Your ability to communicate with family

H. OSafety of you family in their community

I..... OSpouse's job demands or education demands

$\mathrm{J} O$ Chillcare arrangements

K.. OEldercare

L...OChild's'children's education

M.O Serious health or emotional problems of spouse, child, parent, sibling, or elderly family member

N.ODivare ur marital problems

Q.. B Bith or adoption of a child

P...O Your or your spouse's pregancy

Q. O Death of a fanily nember

R. O Major financial hardship or bankruptcy within you family

S. O Major home repair or replacenent due to casualty, theft, fire of severe weather (e.g. huricane, flood, earthquake, tomado)

I. $\mathrm{O}$ Other (specify):

M9918SP / Coding Note 4 
M9919.

19. Hew many days ever the past 12 months have you been detailed for werk nutside the scope of your primary duties (eg., "augmentee" assignments, maintenance tasks, installation suppert, suppert tasking, and wing ready teams)?

2. ONone

1.. 01.10 days

2. 01120 days

3. O21-30 days

4. O $31-40$ days

5. 041.50 days

6. $051-60$ days

7. O More than 60 days

M9920AM9920C

20. How prepared do you believe your unit is te perfora its mission with regard to...?

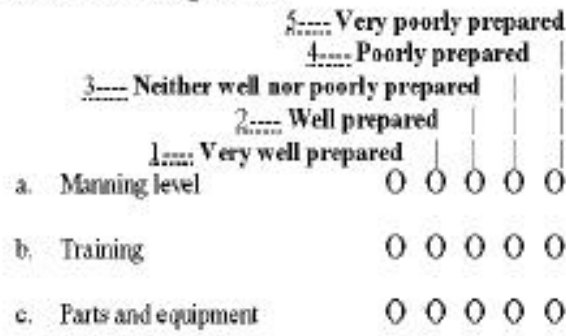

$\mathrm{M} 9921$

21. Suppose you will be in the military for the next 12 eeaths. What is the total leagth of time that yeu would exect to be away frem your permanent duty station because of your military duties?

62. OI would not expect to be away fron my pemanent daty station in the next 12 months

1. O Less than 1 morth

2. 01 month to less than 3 months

3. $O 3$ months to less than 5 months

4. O5 months to less than? months

5. 07 months to less than 10 months

6. O 10 months to 12 months

\section{CAREER INFORMATION}

\section{M992?}

22. What were your career intentioas when you first entered active duty?

1. O I intended to remain on active daty until I was elighle for retirement

2. O I intended to complete my obligation and then leave active duty

3. OI was not sue if I would stay on active duty or leave
M9923A-M9923U/Coding Note 36

23. Think back to when you first entered active duty Which of the following best describe the primary reasons why you joined? (MARK ALL THAT APPLY,

A A. Truble in oollege of break from school

O B. Get away from farrily, personal vituation, or home town

O C. Tims to figure out what you wanted to do

O D. Teet yourelf physically or mental ly

O E. Challeaging or interesting soork

O F. Alvars wantod to be is the military

O G. Military trodition in your fumily

O H. Psents encouragement

O [. Deaise to werve your countr?

$O \quad$ J. Image portryod by militzry persoanel

O K. Fewor no civilian job opportenities

O L. Pay and allowancé( 3 )

O M. Roticementpuy and benefits

O N S Secrity and atsbility of the job

O O. Opporturity to work ir a specific ocenpation

O P. Traning in akills usefu] for civilian smploymont

O Q. Furily benefits

O R. Tranel and new experiences

O 8. Money for college, wollege repgyment, eduestion betuefits ind opportunities

O T. Personal growth and maturity M9924

24. Of all your reasons listed in Question 21, which is the most important reason why gou joloed?

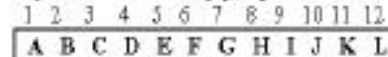
MN O P Q R S T U

$1314151617181920 \%$

MO225

25. ....and which ha the next mart important reasot why you joined?

\begin{tabular}{|l|lllllllllll|}
\hline $\begin{array}{l}1 \\
\text { A }\end{array}$ B & C & D & E & F & G & H & I & J & K & L \\
M N & O & P & Q & R & S & T & U & O N None \\
\hline 13 & 14 & 15 & 16 & 17 & 18 & 19 & 20 & 21 & 0
\end{tabular}

M9g26 / Coding Nobes

26. When you first entered active duty servico, did goe tave : preference for a militery occupation?

10 Yes

2. $\mathrm{ON} \rightarrow \mathrm{On}$ to Quention $28 \mathrm{M} 9925 \mathrm{SK}$

MQ22?

27. Did you recelve the milltary occupation of your choice? 1. OYes

$2 \mathrm{ONJ}$, but I receivsd a relatsd occapation

3. O No, [ roceired an ocoupation unrelated to my ahcios 
M9928

28. How satisfied are you now with the military occupation you received when you first entered active duty?

1.. O Very satisfied

2. O Satisfied

3. O Neither satisfied nor dissatisfied

4. O Dissatisfied

5 O Very dissatisfied

M9929* (0004/E004) Coding Note 6

29. In which term of service are you serving now? (DO NOT COUNT EXTENSIONS AS SEPARATE

TERMS OF ENLISTMENT.) M9929SK

1.. O I am on indefinite status $\rightarrow$ Go to Question 32

2. O I am an officer serving an obligation

3. O 1st enlistment

4. $O$ 2nd or later enlistment

M9930* (E005)

30. How much time remains in your current enlistment term or service obligation?

1.. O Less than 3 months

2. O 3 months to less than 7 months

3. $O 7$ months to less than 1 year

4. $\mathrm{O} 1$ year to less than 2 years

5. O 2 years to less than 3 years

M9931

6. O 3 years or more

31. How likely is it that you would be allowed to stay on active duty service at the end of your current term or service obligation?

1.. O Very likely

2. O Likely

3 . O Neither likely nor unlikely

4. O Unlikely

5. O Very unlikely

M9932.(E027)

32. Suppose that you have to decide whether to stay on active duty. Assuming you could stay, how likely is it that you would choose to do so?

1.. O Very likely

2. O Likely

3. O Neither likely nor unlikely

4. O Unlikely

5. O Very unlikely

M9933(0028)

33. If you stay on active duty, when would you expect your next promotion to a higher grade?

1. O Less than 3 months

2. O 3 months to less than 7 months

3. $O 7$ months to less than 1 year

4. $\mathrm{O} 1$ year to less than 2 years

5. $\mathrm{O} 2$ years or more

63 O Does not apply, I do not expect a promotion

64. O Does not apply, I have no opportunities for promotion
M9934(O030/E028)

34. Does your spouse, girlfriend, or boyfriend think you should stay on or leave active duty?

1. O Strongly favors staying

2.. O Somewhat favors staying

3. O Has no opinion one way or the other

4. O Somewhat favors leaving

5. O Strongly favors leaving

65. O Does not apply, I don't have a spouse or girlfriend/boyfriend

M9935

35. If you could stay on active duty as long as you want, how likely is it that you would choose to serve in the military for at least 20 vears?

1.. O Very likely

2. OLikely

3. O Neither likely nor unlikely

4. OUnlikely

5. O Very unlikely

66. O Does not apply, I have 20 or more years of service M9936*:(O023/E023)/Coding Note 7

36. When you finally leave active duty, how many total years of service do you expect to have?

\begin{tabular}{|l|l|}
\hline & \\
\hline 0 & 0 \\
1 & 1 \\
2 & 2 \\
3 & 3 \\
4 & 4 \\
& 5 \\
& 6 \\
& 7 \\
& 8 \\
& 9 \\
\hline
\end{tabular}

YEARS

For example, if you expect

to leave after completing

6 years of service, enter

"06" in the boxes and fill

in the corresponding

circles. To indicate less

than I year, enter "00."

M9937

37. If you were to leave active duty in the next $\mathbf{1 2}$ months, what would be your primary activity?

1 Attend college or university

2 OWork for civilian company or organization

3 O Work in a civilian government job (local, state, or federal)

4 O Manage or work in family business

5 O Self-employed in your own business or profession

6 OA homemakerhousewife/househusband

70 Go into full-time retirement

8 ONone of the above

M9938(O025/E025)

38. When you leave active duty, how likely is it that you will join a National Guard or Reserve unit?

1. O Very likely

2. O Likely

3 . O Neither likely nor unlikely

4. O Unlikely

5 . O Very unlikely

67. O Does not apply, I am a member of a National Guard or Reserve unit

68. O Does not apply, retiring or otherwise ineligible 
M9939A-M9939KK (O136/E137)

39. How satisfied are you with each of the following? -6----: Does not apply 5 --:-: Very dissatisfied 4---:- Dissatisfied

3---:- Neither satisfied nor dissatisfied 2--:-: Satisfied

\section{A. Basic pay} 1 --:- Very satisfied $|\downarrow|$

B. Special and incentive pay

000000

C. Reenlistment bonus or continuation pay program

D. Housing allowance

000000

000000

E. SEPRATS/COMRATS, O O 000 subsistence allowance

F. Military housing

000000

G. Medical care for you

00000

H. Dental care for you

00000

I. Retirement pay you would get

J. Cost of living adjustment (COLA) to retirement pay

K. Other retirement benefits such as medical care and use of base services

L. Pace of your promotions

00000

M. Chances for future

00000 advancement

N. Training and professional development

O. Type of assignments received

P. Deployments

00000

Q. Other military duties that take you away from permanent duty station

R. Availability of equipment, $\mathrm{O} O \mathrm{O} O \mathrm{O} O$ parts, and resources

S. Level of manning in your

T. Your unit's morale

00000

U. Your personal workload

00000

00000

$$
\begin{aligned}
& -6---- \text { Does not apply } \\
& \text { 5---:- Very dissatisfied } \\
& \text { 4-.-.- Dissatisfied } \\
& \text { 3----: Neither satisfied nor dissatisfied } \\
& \text { 2--:-. Satisfied } \\
& 1 \text {-.-:- Very satisfied }
\end{aligned}
$$

M9940

40. Even if you have no plans to stav, of all the factors listed in Question 39, which is the most important factor for staving or considering staving on active duty?

\begin{tabular}{|ccccccccccccc|}
\hline $\mathbf{A}$ & B & C & D & E & F & G & H & I & J & K & L & M \\
1 & 2 & 3 & 4 & 5 & 6 & 7 & 8 & 9 & 10 & 11 & 12 & 13 \\
N & O & P & Q & R & S & T & U & V & W & X & Y & Z \\
14 & 15 & 16 & 17 & 18 & 19 & 20 & 21 & 22 & 23 & 24 & 25 & 26 \\
AA & BB & CC & DD & EE & FF & GG & HH & II & JJ & KK & \\
27 & 28 & 29 & 30 & 31 & 32 & 33 & 34 & 35 & 36 & 37 & \\
\hline
\end{tabular}
M9941

41. ...and which is the next most important factor for staying or considering staying on active duty?

\begin{tabular}{|ccccccccccccc|}
\hline A & B & C & D & E & F & G & H & I & J & K & L & M \\
1 & 2 & 3 & 4 & 5 & 6 & 7 & 8 & 9 & 10 & 11 & 12 & 13 \\
N & 0 & P & Q & R & S & T & U & V & W & X & Y & Z \\
14 & 15 & 16 & 17 & 18 & 19 & 20 & 21 & 22 & 23 & 24 & 25 & 26 \\
AA & BB & CC & DD & EE & FF & GG & HH & II & JJ & KK & 0 None \\
27 & 28 & 29 & 30 & 31 & 32 & 33 & 34 & 35 & 36 & 37 & 0 & \\
\hline
\end{tabular}


M994?

42. Even if you have no plans to leave of all the factors listed in Question 39, which is the most impertant facter for leaving or considering leaving active duty?

$\begin{array}{lllllllllllll}\text { A } & \text { B } & \text { C } & \text { D } & \text { E } & \text { F } & \text { G } & \text { H } & \text { I } & \text { J } & \text { K } & \text { L } & \text { M }\end{array}$ $\begin{array}{lllllllllllll}1 & 2 & 3 & 4 & 5 & 6 & 7 & 8 & 9 & 10 & 71 & 12 & 13\end{array}$

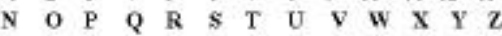
$\begin{array}{llllllllllllll}14 & 15 & 16 & 17 & 18 & 19 & 20 & 21 & 22 & 23 & 24 & 25 & 26\end{array}$ AA BB CC DD EE FF GG HH II JJ KK $\begin{array}{lllllllllll}27 & 28 & 29 & 30 & 31 & 32 & 33 & 34 & 35 & 36 & 37\end{array}$ M9943

43. ... and which is the nert most important factor for leaving or considering leaving active duty?

$\begin{array}{llllllllllllll}\text { A } & \text { B } & \text { C } & \text { D } & \text { E } & \text { F } & \text { G } & \text { H } & \text { I } & \text { J } & \text { K } & \text { L } & \text { M }\end{array}$ $\begin{array}{lllllllllllll}1 & 2 & 3 & 4 & 5 & 6 & 7 & 8 & 9 & 10 & 11 & 12 & 13\end{array}$ $\begin{array}{lllllllllllll}\mathrm{N} & \boldsymbol{O} & \mathrm{P} & \mathbf{Q} & \mathrm{R} & \boldsymbol{S} & \mathrm{T} & \mathrm{U} & \mathbf{v} & \mathbf{W} & \mathbf{X} & \mathrm{Y} & \mathbf{Z}\end{array}$ $\begin{array}{lllllllllllll}14 & 15 & 16 & 17 & 18 & 19 & 20 & 21 & 22 & 23 & 24 & 25 & 26\end{array}$ AA BB CC DD EE FF GG HH II JJ KK 0 Noat $\begin{array}{llllllllllll}27 & 28 & 29 & 30 & 31 & 32 & 33 & 34 & 35 & 36 & 37 & 0\end{array}$

\section{MILITARY LIFE}

M9944A-M $2944 \mathrm{~K}$

44. Hew impertant should the followiag factors be is determining tetal military compensation, including pay, benefits, and allewances?

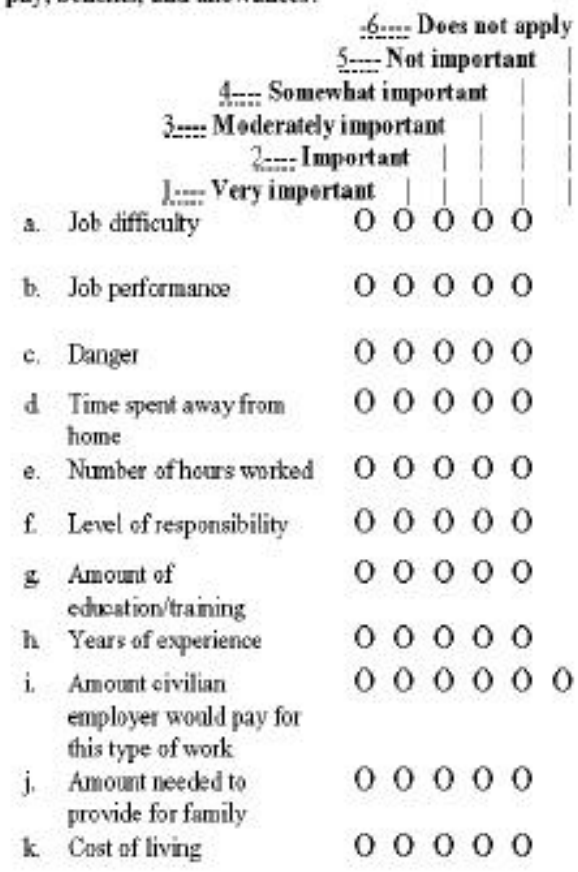

M9945A-M9945J (O129/E130)

45. How much do you agree er disagree with the following st at emeats?

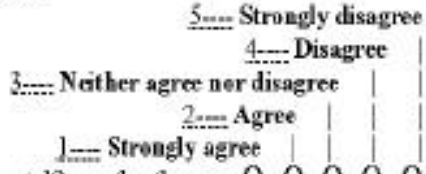

a. Dering the past 12 months, the 00000 miscions I was imvolved with were important to the mational interest

b. During the past 12 mordhs, 00000 most or sll of the military duties I performed mproved or maintained mit or individaal readiness

c. I would find it rewarding to $\quad 00000$ deploy on a peacekeeping/pencemaking operation (e.g., Bosnia)

d. I would find it rewarding to $\mathrm{OOOOO}$ deploy on an overseas humariturian relief effort (e.g. foreign disaster relief such as Nicaragua]

c. Very little of my experience and training can be directly trankferred to a civilian job

f. It would be easy for me to get a $\mathrm{O} O \mathrm{OO}$ good civilian job if I left the militery now

z. I have a pretty good idea of the kinds of jobs I could get 4 s a civilian

h. I have a pretty geod idea of what pay I coold get as a civilian

i. The benefits available to military persornel and their families hwe eroded over the past few years

j. If asked today, I would encourage others to join the 00000 military

M9946

46. In general has your life been better er worse thas you expected when you first entered the military?

1. OMuch better

2. O Somexhat better

3. O About what you expected

4. O Somewhat worse

5. OMach warse

92. O Don't remember 
M9947

47. In general, has your work been better or worse than you expected when you first entered the military?

1. O Much better

2. O Somewhat better

3. O About what you expected

4. O Somewhat worse

5. O Much worse

99 O Don't remember

M9948A-M9948K/Coding Note 36

48. During the past 6 months, have you done any of the following to explore the possibility of leaving the military? (MARK ALL THAT APPLY.)

A. O Thought seriously about leaving the military

B. O Wondered what life might be like as a civilian

C. O Discussed leaving and/or civilian opportunities with family members or friends

D. O Talked about leaving with your immediate supervisor

E. $O$ Gathered information on education programs or colleges

F. $O$ Gathered information about civilian job options (e.g., read newspaper ads, attended a job fair)

G. O Attended a program that helps people prepare for civilian employment

H O Prepared a resume

I. O Applied for a job

J... O Interviewed for a job

$\mathrm{K}$. O None of the above

M9949A-M9949J_(O094/E095_O100/E100)

49. How do your opportunities in the military compare to opportunities you would have in the civilian world?

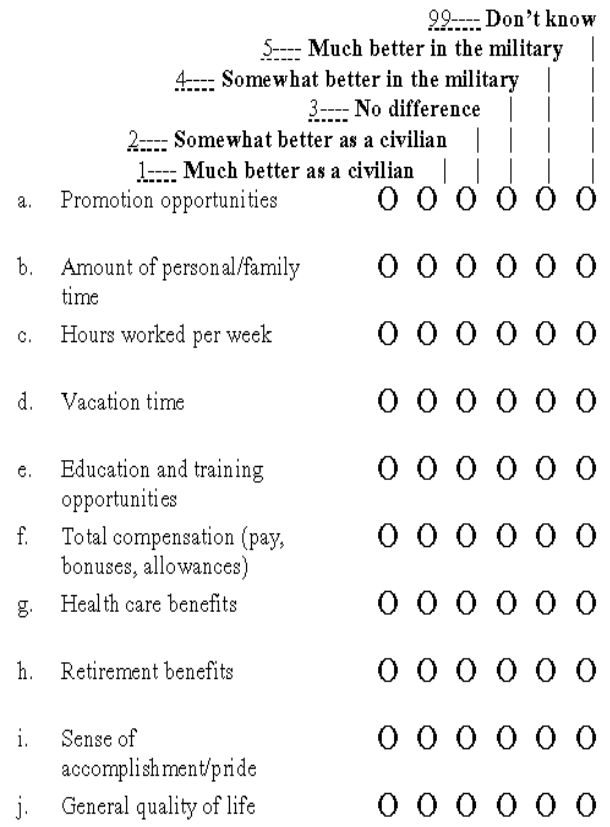

\section{M9950A-M9950M}

50. How much do you agree or disagree with the following statements?

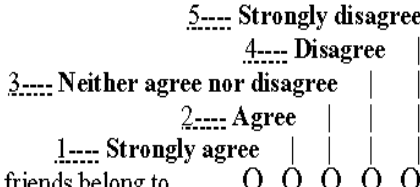

a. Most of my friends belong to

00000 the military community

b. The military community is there $\mathrm{OOOOO}$ for me when I need it

c. I have a lot in common with the $\mathrm{OOOOO}$ civilian community

d. Members of the military

00000 community sometimes turn to me for help or support

e. Living on base helps active duty members and their families make ends meet

f. I talk up my Service to my friends as a great organization to be a part of

g. There is not much to be gained for me by sticking with a military career

h. I am proud to be a member of $\mathrm{O} O \mathrm{O} O \mathrm{OO}$ my Service

i. I find that my values and the values of my Service are very similar

j. Being a member of my Service inspires me to do the best job I can

k. I would turn down another job for more pay in order to remain in my Service

1. My Service's evaluation/ $\quad 0000$ selection system is effective in promoting its best members

m. If I stay in the Service, I will be $\mathrm{O} O \mathrm{O} O \mathrm{O}$ promoted as high as my ability and effort warrant

00000

00000

00000

M9951(O137/E138)

51. Now, taking all things together, how satisfied are you with the military way of life?

1.. O Very satisfied

2. O Satisfied

3.. O Neither satisfied nor dissatisfied

4. ODissatisfied

5 O Very dissatisfied 
PROGRAMS AND SERVICES

MA952A01-MA952A13 MA952B01-MA952B13/MU952A01-MU952A13 MU952B01-MU952B13 (0192/E102)

52. On average during a month, bow oftea do you use the following an base programs, facilities, or services and civilian off base pregrams, facilities, or services?

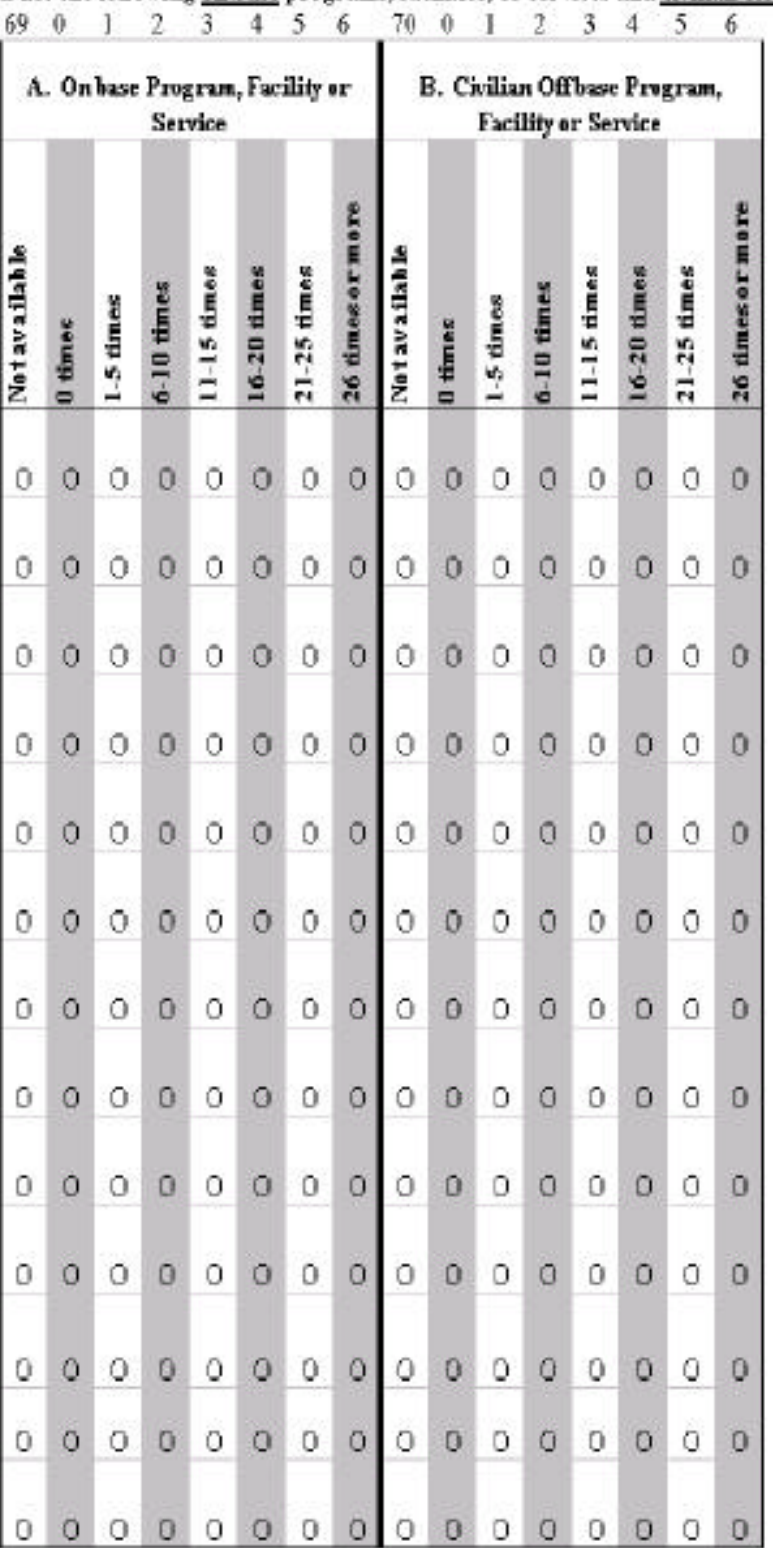

For each of thase 13 items, trark one responst in coluan $A$ and cone response in coluan $B$

\begin{tabular}{|c|c|c|c|c|c|c|c|c|c|c|c|c|c|c|c|c|}
\hline 1. Fituese CortenlGyin. & 0 & 0 & 0 & 0 & 0 & 0 & 0 & 0 & 0 & 0 & 0 & 0 & 0 & a & 0 & 0 \\
\hline 2 Library struces. & 0 & 0 & 0 & 0 & 0 & 0 & 0 & 0 & 0 & 0 & 0 & 0 & 0 & 0 & 0 & 0 \\
\hline $\begin{array}{l}\text { 3. Oudidour tecreation ateas (e.g, cartpgrounds, picnse } \\
\text { areas, beach, stobles) }\end{array}$ & 0 & 0 & 0 & 0 & 0 & 0 & 0 & 0 & 0 & 0 & 0 & 0 & 0 & 0 & 0 & 0 \\
\hline 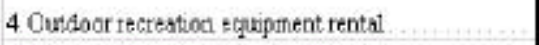 & 0 & 0 & 0 & 0 & 0 & 0 & 0 & 0 & 0 & 0 & 0 & 0 & 0 & 0 & 0 & 0 \\
\hline 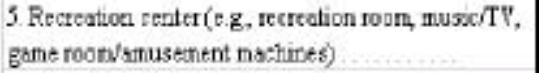 & 0 & 0 & 0 & 0 & 0 & 0 & 0 & 0 & 0 & 0 & 0 & 0 & 0 & a & 0 & 0 \\
\hline 6 Golf course & 0 & 0 & 0 & 0 & 0 & 0 & 0 & 0 & 0 & 0 & 0 & 0 & 0 & 0 & 0 & 0 \\
\hline 7 Bouling center. & 0 & 0 & 0 & 0 & 0 & 0 & 0 & 0 & 0 & 0 & 0 & 0 & 0 & 0 & 0 & 0 \\
\hline 8. Recreation lofiging/hotel ar resocts .............. & 0 & 0 & 0 & 0 & 0 & 0 & 0 & 0 & 0 & 0 & 0 & 0 & 0 & 0 & 0 & 0 \\
\hline 9. Clube/danceinight clutas. & 0 & 0 & 0 & 0 & 0 & 0 & 0 & 0 & 0 & 0 & 0 & 0 & 0 & 0 & 0 & 0 \\
\hline 10. Conurissagyieupemarkat/grocery store. & 0 & 0 & 0 & 0 & 0 & 0 & 0 & 0 & 0 & 0 & 0 & 0 & 0 & 0 & 0 & 0 \\
\hline II. Mün ezchange/departaenl gtore . & 0 & 0 & 0 & 0 & 0 & 0 & 0 & 0 & 0 & 0 & 0 & 0 & 0 & 0 & 0 & 0 \\
\hline 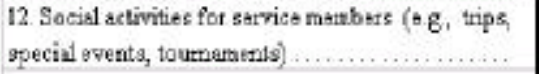 & 0 & 0 & 0 & 0 & 0 & 0 & 0 & 0 & 0 & 0 & 0 & 0 & 0 & 0 & 0 & 0 \\
\hline 13. Auto, crafls and hobbry shors. & 0 & 0 & 0 & 0 & 0 & 0 & 0 & 0 & 0 & 0 & 0 & 0 & 0 & 0 & 0 & 0 \\
\hline
\end{tabular}

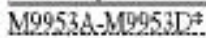

53. During the past 12 months, have you used any of the following programs and services? (MARK ONE ANSWER IN EACH ROW.)
a. Adul contimuing education courseling

$\begin{array}{cc}\text { Hes........ } & 2 \\ \text { Yes } & \text { No } \\ 0 & 0 \\ 0 & 0 \\ 0 & 0 \\ 0 & 0\end{array}$




\section{FAMILY INFORMATION}

SRMARST * (O044:E045]/CodingNate 8 / Coding Note 9

54. What is your manital status?

1. O Now married

2. O Separated

3. O Divorced $\rightarrow$ Go to Question 57 M9954SKA

4. W Widowed $\rightarrow$ Go to Question 57

5. O Never married $\rightarrow$ Go to Question 58

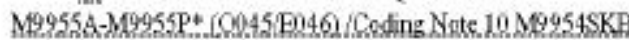

55. Is yeur spense currently: (MARK ALL THAT

APPLY.)

A. OServing on active dity (not $*$ member of the National Guard or Reserve)

B. OMenber of the National Guard or Resene in a fall-time active duty program (AGR, TAR, AR)

C. O Other type of National Guard or Resenve member (e.g, drilling unit, IMA, IRR, military technician)

D. 0 Werking in a Federal civilian job (full-time)

E. Warking in a Federal civilian job (part-tine)

F. $O$ Working in a civilian jab on base (full-time)

$\mathrm{G} O$ Working in a civilian job on base (part-time)

H. OWarking in a civilian job off base (full-time)

I... W Working in a civilian job off base (part time)

I. O Managing $\alpha$ working in family busines

K. OSelf-employed in hisher exn business or profession

L. O Unemployed and looking for work

M O In school

N. O Homemaker/housewife housebusband

0 ORetired

B. OOther (specify):

M9955sP. [Coding Note.10

PREDUCAREDUCA.PREDUCH PREDHI'LCoding Note.1]

56. What is the highest degree or level of scheol that

veur spouss has completed? (MARK THE ONE

ANSWER THAT DESCRIBES THE HIGHEST

GRADE OR DEGREE THAT YOUR SPOUSE HAS

COMPLETED.)

A. OIlth grade or less

B. O 12 years of schanl, no diploma

C. O High school gaduate - high school diplona or the equivalent ( $\mathrm{e} g$, GED)

D. O Some college credit, but less than 1 year

E. O1 or more years of college, but no degree

F. O Assoiate degee (e.g, AA, AS)

G. O Bachelor's degee (e.g, BA, AB, BS)

H. OMaster's, doctural degree, ar professiensl school degree (eg. MAMS/PhDMD/DDDVM) $\mathrm{M} 9957^{*}(0054 \mathrm{E} 055)$

57. Hew many times bave you been diverced?

a. $O$ None

1. 01

200

3. 3 er more
For questions in this section, the definition of "child or childrea" or "ether legal dependents" indudes anyone in your family, excent yeurspouse, who has or is eligible to bave a Uniformed Services ideatification card (military ID card) or is eligible for military heal th care benefits and is earolled in the Defense Enrollment Eligibility Reporting System (DEERS)

M9958 i Coding Note.1?

58. Do yeu have a child, children or ether legal dependeats based on the definitiea above? 10 Yes

2. ONa $\rightarrow$ Go to Question 73 M9958SK

M9959A-M9959G (0058/O559)

59. Hew many children or other legal dependeats de you have in each age group? (MARK ONE ANSWER IN EACH $\underline{\text { ROW. }}$.

\begin{tabular}{|c|c|c|c|c|c|c|c|}
\hline & \multicolumn{6}{|c|}{ D.1. $2-3-4$} \\
\hline & Aga & Sons & 1 & 2 & 3 & 4 & momer \\
\hline 3. & Under 1 year old. & 0 & 0 & 0 & 0 & 0 & 0 \\
\hline b. & 1 yoar to un der 2 years old & 0 & 0 & 0 & 0 & 0 & 0 \\
\hline a & $2-5$ years old. & 0 & 0 & 0 & 0 & 0 & 0 \\
\hline d. & $6-13$ years old. & 0 & 0 & 0 & 0 & 0 & 0 \\
\hline$=$ & $14-22$ years old. & 0 & 0 & 0 & 0 & 0 & 0 \\
\hline f. & 23-64 years old. & 0 & 0 & o & 0 & o & 0 \\
\hline g. & 65 years old or older. & 0 & 0 & 0 & 0 & 0 & 0 \\
\hline
\end{tabular}

M9960A-M99600 (0059/B060)

69. Hew many children or other legal dependeats de you have in each of the following age groups whe live oa a rezular basis with vou at yeur permanent duty station? (MARK ONE ANSWER IN RACH ROW.)

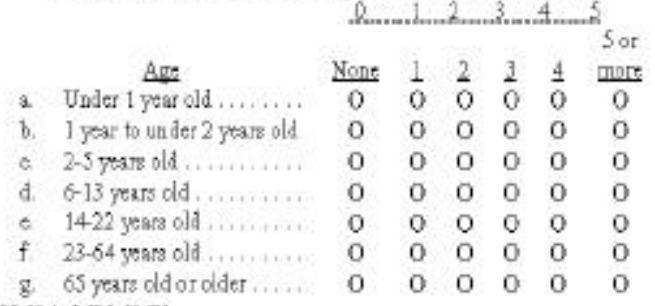
M926LA-M926lG:

61. How many children or other legal dependeats do you have in each of the following age groups whe live on a regular basis at a different location than your permanent duty station? (MARK ONR ANSWER IN EACH BOW.)

\begin{tabular}{|c|c|c|c|c|c|c|c|}
\hline & $A g$ & Yone & 1 & 2 & 1 & 4 & mon \\
\hline 2 & Under 1 gear old .......... & 0 & $\overline{0}$ & $\overline{0}$ & 0 & $\overline{0}$ & 0 \\
\hline b. & l year to un der 2 yeare old & 0 & 0 & 0 & 0 & 0 & 0 \\
\hline 6 & $2-5$ pars old $\ldots . . . . . .$. & 0 & 0 & 0 & 0 & 0 & 0 \\
\hline d. & $6-13$ pears old ............ & 0 & 0 & 0 & 0 & 0 & 0 \\
\hline e & $14-22$ years old. & 0 & 0 & 0 & 0 & 0 & 0 \\
\hline$f$ & $23-64$ years old . ........... & 0 & 0 & 0 & 0 & 0 & 0 \\
\hline$g$ & 65 peart old or older ....... & 0 & 0 & 0 & 0 & 0 & 0 \\
\hline
\end{tabular}


M9962A-M9962R (O068/E069)/Coding Note 13

62. During the past 12 months, have you routinely used any of the following childcare arrangements? (MARK ALL THAT APPLY.)

A. O Not applicable, I have not used any of the

following childcare arrangements $\rightarrow$ Go to Question 68 M9962ASK

B O Child's other parent or stepparent

C. OChild's brother or sister (aged 15 or older)

D O Child's brother or sister (under the age of 15)

E O Child's grandparent

$\mathrm{F} O$ Other relative

G. O Friend or neighbor

$\mathrm{H}$ O Sitter, nanny, or au pair

I.. O Preschool (on base)

J. O Preschool (off base)

K. O"Child Development Center" (on base)

L O Childcare center/day care center (off base)

M. O "Family Childcare Home" (on base)

N O Childcare provider in a home setting (off base)

o. O "School-Age Care Program" (on base)

$P$ OAfter-school program (off base)

Q. O Federally supported Head Start program

$\mathrm{R}$ ONone of the above

M9963

63. How many of your children routinely use the childcare arrangements marked in Question 62?

1 . $\mathrm{O} 1$

2. $\mathrm{O} 2$

3. $\mathrm{O} 3$

4. $\mathrm{O} 4$

5. $\mathrm{O} 5$ or more

M9964A/Coding Note 14 M9964B* (O070/E070)/Coding Note 15

64. What is the total amount that you spent last month on childcare arrangements for all of your children? A. O Does not apply, I spent no money on childcare arrangements last month M9964ASK

B MONTHLY

CHILDCARE
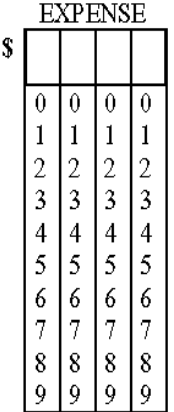

00

Write your monthly expense in the boxes, then fill in the corresponding circles. For example if you spent $\$ 100$ last month, you would enter "0100."

M9965/Coding Note 16

65. During the past 12 months, was there any change in your childcare arrangements for your child or children?

1.. O Yes

2. $\mathrm{ONo} \rightarrow$ Go to Question 68 M9965SK
M9966A-M9966M

66. For what reasons did the childcare arrangements change? (MARK ALL THAT APPLY.)

A. O Beginning, ending, or changes in a child's school enrollment

B O Beginning, ending, or changes in military assignment

C O Beginning, ending, or changes in spouse's school enrollment

D. O Cost

E. O Availability or hours of care provider

F O Reliability of care provider

G. O Quality of care provided

H. O Care provider's location or accessibility

I... O Never had any regular arrangement

J O Child outgrew arrangement

$\mathrm{K}$. O No longer eligible for assistance

L O Arrangement no longer available

M. OOther (specify):

M9967

$$
\text { M9966SP / Coding Note } 17
$$

67. During the past 12 months, did you lose anv time from your military duties (work, school, or training) due to a change in childcare arrangements?

1. OYes

2. ONo

M9968/Coding Note 18

68. Do you have a child or children enrolled in school?

1 OYes

2. $\mathrm{ONo} \rightarrow$ Go to Question 73 M9968SK

M9969: (O068/E069 O072/E073)/CodingNote 19

69. What type of school does your youngest school-age child attend?

1. O College or university $\rightarrow$ Go to Question 73

2. O Public school off base

M9969SK

3. OPublic school on base

4. ODoD school for dependents

5. OA religion-affiliated school

6 O A private day school, not religion-affiliated

7. OA private boarding school

8 O Home school

9. OOther (specify):

$$
\text { M9969SP/Coding Note 20 }
$$

M9970* / Coding Note 21

70. About how many hours per week does your child usually spend in school? (If you have more than one child, answer for the youngest school-age child.)

\begin{tabular}{|l|l|}
\hline & \\
\hline 0 & 0 \\
1 & 1 \\
2 & 2 \\
3 & 3 \\
4 & 4 \\
5 & 5 \\
6 & 6 \\
7 & 7 \\
8 & 8 \\
9 & 9 \\
\hline
\end{tabular}

Write the number of hours in

the boxes, then fill in the

corresponding circles. 
M9971A-M9971G

71. For the type of school you marked in Question 69, please rate the following. -6---:- NA/DK = Not applicable or don't know $5=\mathbf{E}=$ Fai 3---: C $=$ Satisfactory - B $=$ Good

a. Overall academic 1.--: A = Excellent program

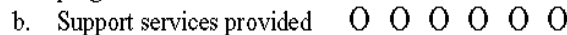
by the school

c. Special education programs

d. Physical plant (building, $\quad 0000000$ school grounds,

heating/cooling, food service, etc.)

e. Availability of extracurricular activities

f. Safety of school

0000000

g. Overall quality of the school

M9972A-M9972F

72. Have you participated in, or been involved with, the following activities related to your child's or children's education? (MARK ALL THAT APPLY.)

A O Attending conferences or meetings with teachers regarding the school

B O Working with teachers to promote achievement

C. O Collaborating on educational opportunities for students, parents, and teachers

D. O Planning and implementing curricular and extracurricular activities

E. OParticipating in decision making and problem solving to promote learning

F O None of the above

M9973* (O074/E075)

73. Do you have a child, spouse, or other legal dependent enrolled in the Exceptional Family Member Program (EFMP) or the Coast Guard Special Needs

Program?

1. OYes

2. ONo

M9974(O076/E077)/Coding Note 22

74. Do you have caregiver responsibilities for an elderly family member (shopping, home maintenance, transportation, checking on them by phone, finances, arrangements for care, etc.)? (This includes persons who live with you or live somewhere else.) 1 OYes

2. $\mathrm{ONo} \rightarrow$ Go to Question 77 M9974SK
M9975

75. How many elderly family members do you have caregiver responsibilities for?

1.. O One

2. OTwo

3 Three or more

M9976

76. During the past 12 months, did you lose any time from your military duties due to eldercare responsibilities?

1.. OYes

2 ONo

M9977A-M9977H/Coding Note 23

77. How satisfied or dissatisfied are you with each of the following aspects of military health care for your family?

H. O Does not apply, I do not have any family members eligible to receive military health care. $\rightarrow$ Go to Question $78 \quad$ M9977HSK

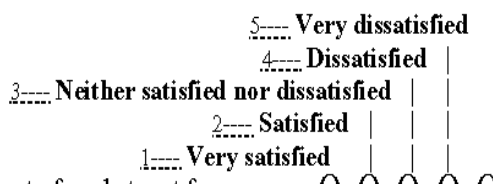

a. My out-of-pocket cost for care 00000

b. Skill of physicians and other 00000 medical providers

c. Availability of specialists $\quad 00000$

d. Ability to get appointments 00000

e. Waiting time in the clinic 00000

f. Overall quality of care $\quad 00000$

g. Administrative requirements 00000 (claims, paperwork, approvals, etc.)

M9978(O105/E106)/Coding Note 24

78. In the last month, did you perform any non-military volunteer work?

1. O Yes $\rightarrow$ Go to Question 80 M9978SK

2. $\mathrm{ONo}$

M9979A-M9979F

79. What were your reasons for not volunteering? (MARK ALL THAT APPLY.)

A. O I was not asked to perform volunteer work

B O I did not have time for volunteer work

C. O I did not have access to childcare so I could perform volunteer work

D. OI am not interested in volunteer work

E. OI did not have transportation

F.. ONone of the above 
M9989

80. How is your general outloek abeut your life?

1. O Very optimistic

2. Optimistic

3. ONeither optimistio nor pessimistio

4 OPessimistic

5. OVery pessimistic

M998 LCoding Note25

81. Are you accempanied by family menbers (spouse, child, or other legal dependents) at your permanent duty station?

1. OYes $\rightarrow$ Go to Question 83 M9g8ISK

2. ONo

M9982A-M0982L:

82. Why didu't your family members accompany you to your permanent duty station? (MARK ALL THAT APPLY.)

A. O Does not apply, I have no family menbers

E. O Legal separation or divarce from spouse

c. O Temporarily unacoconpanied (fanuily members will join me hater)

D. O Pemanently unaccompanied lecanse it was required for the authorizaticoubillet

E. OPermanertly unacsampanied becanse family members were not command spunsored (overseas tour)

E. OPermanently unsccompanied becanse household goods move was not anthorized with PCS orders

G. O Spouse's career

F. $O$ Spoure's education

I. OChild'sichildren's edusation

I. OHealth or illness of family member

K. O Eldercare responsibilities

I. OOther (specify):

\section{M9082SP Crinz Note 26}

M9983* $0017 / \mathrm{E} 0172$

83. During your active duty career, how many times did veur family members move to a new location because of your permanent change of station $(\mathrm{PCS})$ ?

.2. None

6. 06

1. 01

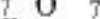

20

${ }_{3}^{3} 0 \quad 0$

$4.0 \quad 4$

5. 0

M9984A-MO984I: Coding Note 36

84. Have any of your relatives ever served on active military duty? (MARK ALL THAT APPL Y.

A OParent ar guardian

‥ OSpouse

C. OBrother or sister

D. O Son or davghter

E. O Grandparent

E. OUncle or sunt

G. $\mathrm{O}$ Cousin

5. $O$ Other close relative

1. ONone of ny relatives have served on active duty

\section{ECONOHIC ISSUES}

The questions in this sectien address economic isues in the lives of military members and thair families. The information will be used to better understand the ecenemic and financial conceras of military members and their families. Altbough peeple will have different views on what is or is not personal, many people will ceasider some of the questions very personal. Please continue with the survey even if there are some questions that you want to skip.

M9985/CodingNote 27

85. During your eff-duty time, de you currently bold a second job or work at your own business? 2. OYes

2. $\mathrm{ON}_{0} \rightarrow \mathrm{Go}$ to Question 8T MPQ85SK M9986* (Ol07.8108) / Coding Note 28

86. On average, bow many hours a week do you sped working at a divilian job or working at yøur own business during your off-duty bours?

\begin{tabular}{|l|l|}
\hline & \\
\hline 0 & 0 \\
1 & 1 \\
2 & 2 \\
3 & 3 \\
4 & 4 \\
5 & 5 \\
6 & 6 \\
7 & 3 \\
8 & 8 \\
9 & 9 \\
\hline
\end{tabular}

\section{HOURS PER WEEK}

For example, if jou worked

8 howers, enter " 08 " in

the bores and ful in the

Corresponding cincles.

M9987A-M9097L_(O117/E118)/Coding.Note 36

87. During the past 12 menths, did you (and your spouse) receive any iBcome or financial sappert from the following sources? (MARK ALL THA'

APPLY,)

A OA second job

B. OAlimony

C. O Child support

D. OSupplemental Security Incame (SSI)

E. O Unemployment or Worker's compensation

F. O State-fimded childeare assistance

9. OWomen, Infants, and Children (WIC)

H. O Food Stamp Progam

I. OHead Start Progam

I. O Aid to Families with Dependent Children (AFDC)

X. OMedicaid

I. O Other (specify)

M9982SP / Coding Note 29 
M9988

88. What is your total monthly gross (before-tax) household income from all sources? (Please include your military earnings, your earnings from a second job, your spouse's earnings, and income or financial support from any other source.)

1. $0 \$ 1-1,000$

$20 \$ 1,001-2,000$

3. $O \$ 2,001-3,000$

4 O\$3,001-4,000

5. $O \$ 4,001-5,000$

$60 \$ 5,001-6,000$

Z. $O \$ 6,001-7,000$

$80 \$ 7,001-8,000$

9. $O \$ 8,001-9,000$

10. $O \$ 9,001-10,000$

M9989

11. $O \$ 10,001$ and above

89. Roughly, what is the total amount of savings you (and your spouse) have? (Please include funds in bank accounts, IRAs, money market accounts, Certificates of Deposit (CDs), Savings Bonds, mutual funds, stocks and/or bonds.)

0 O\$0

1. $O \$ 1-1,000$

2. $O \$ 1,001-2,500$

3. $O \$ 2,501-5,000$

$40 \$ 5,001-7,500$

5 O\$ $7,501-10,000$

6 O $\$ 10,001-12,500$

7. $O \$ 12,501-15,000$

8 O $\$ 15,001-17,500$

9. $O \$ 17,501-20,000$

10. $O \$ 20,001-50,000$

$110 \$ 50,001-100,000$

12. $O \$ 100,001$ and above

M9990.M061/E062

90. Do you (or your spouse) pav child support?

1. O Yes, I pay child support

2 OYes, my spouse pays child support

3 O Yes, both my spouse and I pay child support

4. ONo

M9991

91. What is the total amount you (and your spouse) paid last month for rent or mortgage?

$0.0 \$ 0$

1 $O \$ 1-400$

2. $O \$ 401-800$

3. $O \$ 801-1,200$

$4 \mathrm{O} \$ 1,201-1,600$

5. $O \$ 1,601-2,000$

$60 \$ 2,001$ and above
M9992

92. What is the total amount you (and your spouse) paid last month for all loans and leases on cars, trucks, or motorcycles?

0. $0 \$ 0$

$10 \$ 1-250$

2. $O \$ 251-500$

3. $O \$ 501-750$

4. $O \$ 751-1,000$

5 O\$1,001-1,250

6. $O \$ 1,251-1,500$

M9993

$0 \$ 1,501$ and above

93. What is the amount of payments that you (and your spouse) made last month to cover personal unsecured debt? (Include all credit cards, debt consolidation loans, AAFES loans, NEXCOM loans, student loans, and other personal loans; exclude home mortgage and car loans)

$0.0 \$ 0$

1. $O \$ 1-150$

2. $O \$ 151-300$

$3 . \$ 301-450$

4. $O \$ 451-600$

5. $0 \$ 601-750$

$60 \$ 751-900$

7. $0 \$ 901-1,050$

8 O $\$ 1,051$ and above

M9994

94. After the last payment was made on personal unsecured debt, what was the total amount you (and your spouse) still owed? (Include all credit cards, debt consolidation loans, AAFES loans, NEXCOM loans, student loans, and other personal loans; exclude home mortgage and car loans)

$0.0 \$ 0$

$10 \$ 1-1,000$

2. $O \$ 1,001-2,500$

3. $0 \$ 2,501-5,000$

4. $O \$ 5,001-7,500$

$5.0 \$ 7,501-10,000$

6. $O \$ 10,001-12,500$

7. $\mathrm{O} \$ 12,501-15,000$

8. $O \$ 15,001-17,500$

9. $O \$ 17,501-20,000$

M9995

10. $O \$ 20,001$ and above

95. Which of the following best describes the financial condition of you (and your spouse)?

1. O Very comfortable and secure

2. O Able to make ends meet without much difficulty

3. O Occasionally have some difficulty making ends meet

4. O Tough to make ends meet but keeping your head above water

5. O In over your head 
M9806A-M09960)Crsting Note 36

96. In the past 12 months, did any of the following bappen to you (and your spouse)? (MARK ALL THAT APPLY)

A. $O$ Bounced two or more checks

B. OReceived a letter of insebtedness (e.z, a letter from a lender to your commanding office that pasment is late)

C O Had your wages gamished

D. OFell behind in paying your rent or mortgage

E OFell behind in prying your credit card, AAFES, or NEXCOM aceourt

F. $O$ Was pressued to pay bills by stores, creditors, or bill collectors

G. OHad a bill collector contact your unit leader

H. O Parned or sold valuables to make ends neet

I. OBorrowed money from friends or relatives to help you with a financial difficulty

I. O Borrowed money though an Emergency Laan Assistance Program or a Service Aid Society

K. OHad your utilities (telephone, cable, water, heat or electricity) stout off

L O Had a car, household appliances, or fumiture repossessed

M $O W_{\text {as }}$ unble to afford needed medical care

N OWent benkrupt (declaed personal bankruptcy)

0 ONone of the above

A Thrift Savings Plan (TSP) is a tax-deferred retirement savings plan like a 4010 kj plas.

- Employes may deposit a pertion of their pay itysically up to 5 or 14 percenth before taxes into a long-term fond to provide savings for retiremeat.

- Emoloyerr may match aone, some, or all of thelr tmployees* contributions.

- A wide rage of iovestmeat options is geatrally avallable, including funds that follow the stock and bond markets.

- TSP funds may be taken to another employer or rolled over into other qualiffed retirement savings plans.

- Funds may begin to be withdrawn at around age 59k--tarlier withdrawals are wovalls yetalbed.

M9997A.M9997C

97. If this type of plan were made available to you, how likely would you be to participate is each of the followieg situations?

a. If there were no govenmen Neither likely ner unlikdy 3-in: Very unlikely 4-.... Unlikely matching

b. If the goverrment matched your contribution up to $5 \%$ of pay

c. If you could invest any reenlistment or continuation bonas into the fond tax-deferred
M9908

98. Which, if any, of the following is your main concers about the military retirement system?

-6. ODoes not apply, I have no conoems

1. ONo pension benefits are esmed unless you serve at least 20 years

2. $O$ No ability to save teward retirement with a $401(\mathrm{k})$ of ofher retirement avings progsam

1. O The governmert does not matchany money you put away for retienent

4. O You cannot transfer your retirement benefits to another employer

M9999

5 Ootler

99. Currently, military perseanel do act qualify for refirement benefits unless they serve for at least 20 years. If the system were changed so that you became eligible after at least 10 years of service for a deferred pensien paysble at age 62 , bow much infuence would this baye on your willingness to stay in the military until at least the 16-year point?

7.. O Does not apply, I have aleady served 10 years

72 ODoes not apply, I already intend to stay

2. O Little or no influence

2. $O$ Some influence

3. OModerate infloence

4 O Strong influence

Mag10.

106. Congress is considering a proposal to modify the retirement pay formula for those whe eatered the service on or after August 1, 1986 to the same formula that applied to those who eatered before that date. Assuming the retirenent pay formula were changed, bow much influence would this have on your willingness to stay in the military?

72. This would not affect me since I entered the earvice before August I, 1986

72. O Does not apply, I already intend to say

1. O Little or no influence

2. O Sume influnce

3. OModerate influence

4. $O$ strong influence

\section{BACKGROUND INFORMATION}

SRSEX* $(0052$ E033)

101. Are you

1. OMale

O O Female

SRESL

102. Is English a secend language for you?

1. OYes

$2 \mathrm{ONo}$ 
SRHISP: (O036/E037)

103. Are you Spanish/Hispanic/Latino? (MARK "No" IF NOT SPANISH/HISPANIC/LATINO.)

1 ONo, not Spanish/Hispanic/Latino

2 OYes, Mexican, Mexican American, Chicano

3 O Yes, Puerto Rican

4. OYes, Cuban

5 O Yes, other Spanish/Hispanic/Latino

SRRACEA-SRRACEF* (O035/E036)/Coding Note 30

104. What is your race? (MARK ONE OR MORE RACES TO INDICATE WHAT YOU CONSIDER YOURSELF TO BE.)

A. OWhite

B O Black or African-American

C. O American Indian or Alaska Native

D. O Asian (e.g., Asian Indian, Chinese, Filipino, Japanese, Korean, Vietnamese)

E. O Native Hawaiian or other Pacific Islander (e.g., Samoan, Guamanian, or Chamorro)

F. O Some other race (specify):

SRRACESP/Coding Note 30

M99105*/M99105A-M99105H*/M99105H年_0038/E039) Coding Note 31

105. At the time you first came on active duty, how much education had you completed? (MARK THE ONE ANSWER THAT DESCRIBES THE HIGHEST GRADE OR DEGREE THAT YOU HAD COMPLETED.)

A. O 11th grade or less

B. O 12 years of school, no diploma

C. O High school graduate - high school diploma or the equivalent (e.g, GED)

D. O Some college credit, but less than 1 year

E. $\mathrm{O} 1$ or more years of college, but no degree

F. O Associate degree (e.g., AA, AS)

G. O Bachelor's degree (e.g., BA, AB, BS)

H. O Master's, doctoral degree, or professional school degree (e.g., MA/MS/PhD/MD/JD/DVM)

SRED*/SREDA-SREDH*/SREDHI* (O039/E040)/Coding Note 32

106. What is the highest degree or level of school that you have completed? (MARK THE ONE ANSWER THAT DESCRIBES THE HIGHEST GRADE OR DEGREE THAT YOU HAVE COMPLETED.)

A. O 11th grade or less

B. O 12 years of school, no diploma

C. O High school graduate - high school diploma or the equivalent (e.g, GED)

D. O Some college credit, but less than 1 year

E. $\mathrm{O} 1$ or more years of college, but no degree

F.. O Associate degree (e.g., AA, AS)

G. O Bachelor's degree (e.g., BA, AB, BS)

H. O Master's, doctoral degree, or professional school degree (e.g., MA/MS/PhD/MD/JD/DVM)
M99107:/Coding Note.33

107. Are you currently serving on active duty and/or in the Guard/Reserve?

1. O Yes, serving on active duty (not a member of the Guard/Reserve)

2. OYes, a member of the Guard/Reserve in a full-time active duty program (AGR, TAR, AR)

3. O Yes, other type of Guard/Reserve member (e.g. drilling unit, IMA, IRR, military technician)

4. ONo $\rightarrow$ Go to Question 110 M99107SK

SRSVC* (Comment).

108. In what Service are you?

$$
\begin{array}{lllll}
1 . \mathrm{O} & \text { Army } & 4 . \mathrm{O} & \text { Air Force } \\
2 . & \mathrm{O} & \text { Navy } & 5 . \mathrm{O} & \text { Coast Guard } \\
3 . & \mathrm{O} & \text { Marine Corps } & &
\end{array}
$$

SRGRADE* (O003/E003)

109. What is your current paygrade?

$\begin{array}{lllllllll}1 . & \mathrm{O} & \mathrm{E}-1 & 10 & \mathrm{O} & \mathrm{W}-1 & 1.5 & \mathrm{O} & \mathrm{O}-1 \\ 2 & \mathrm{O} & \mathrm{E}-2 & 11 & \mathrm{O} & \mathrm{W}-2 & 16 & \mathrm{O} & \mathrm{O}-2 \\ 3 & \mathrm{O} & \mathrm{E}-3 & 12 . & \mathrm{O} & \mathrm{W}-3 & 17 & \mathrm{O} & \mathrm{O}-3 \\ \mathbf{4} & \mathrm{O} & \mathrm{E}-4 & 13 & \mathrm{O} & \mathrm{W}-4 & 18 & \mathrm{O} & \mathrm{O}-4 \\ 5 & \mathrm{O} & \mathrm{E}-5 & 14 \mathrm{O} & \mathrm{W}-5 & 19 & \mathrm{O} & \mathrm{O}-5 \\ \mathbf{6} & \mathrm{O} & \mathrm{E}-6 & & & & 20 & \mathrm{O} & \mathrm{O}-6 \text { or above } \\ 7 . & \mathrm{O} & \mathrm{E}-7 & & & & & \\ 8 & \mathrm{O} & \mathrm{E}-8 & & & & & \\ 9 & \mathrm{O} & \mathrm{E}-9 & & & & & \end{array}$

M99110* / Coding Note 34

110. How many years of active duty service have you completed?

\begin{tabular}{|l|l|}
\hline & \\
\hline 0 & 0 \\
1 & 1 \\
2 & 2 \\
3 & 3 \\
4 & 4 \\
5 & 5 \\
& 6 \\
& 7 \\
& 8 \\
& 9 \\
\hline
\end{tabular}

\section{YEARS}

For example, if you have completed 3 years of service, you would enter "03." To indicate less than 1 year, enter "00."

SRDATEMM*/SRDATEDD* / SRDATEYY* / SRDATE / Coding Note 35

\begin{tabular}{|c|c|c|}
\hline MONTH & DAY & $\overline{\text { YEAR }}$ \\
\hline O January & & $\begin{array}{l}01999 \\
\end{array}$ \\
\hline O February & & O 2000 \\
\hline O March & 0 & \\
\hline O April & 1 & \\
\hline O May & 2 & \\
\hline o June & 3 & \\
\hline O July & 4 & \\
\hline O August & 5 & \\
\hline O September & 6 & \\
\hline O October & 7 & \\
\hline O November & 8 & \\
\hline O December & 9 & \\
\hline
\end{tabular}

111. What date did you complete this survey? DATE 
COMMENT/Codiog Note 3 ?

COMMENTS

112. If yeu have conments or cenceras that you were not able te express in answeriag this survey, please write them in the space previded. If your comments relate to spedific questiens on this survey, please nake a note of the question number beside your cemment.

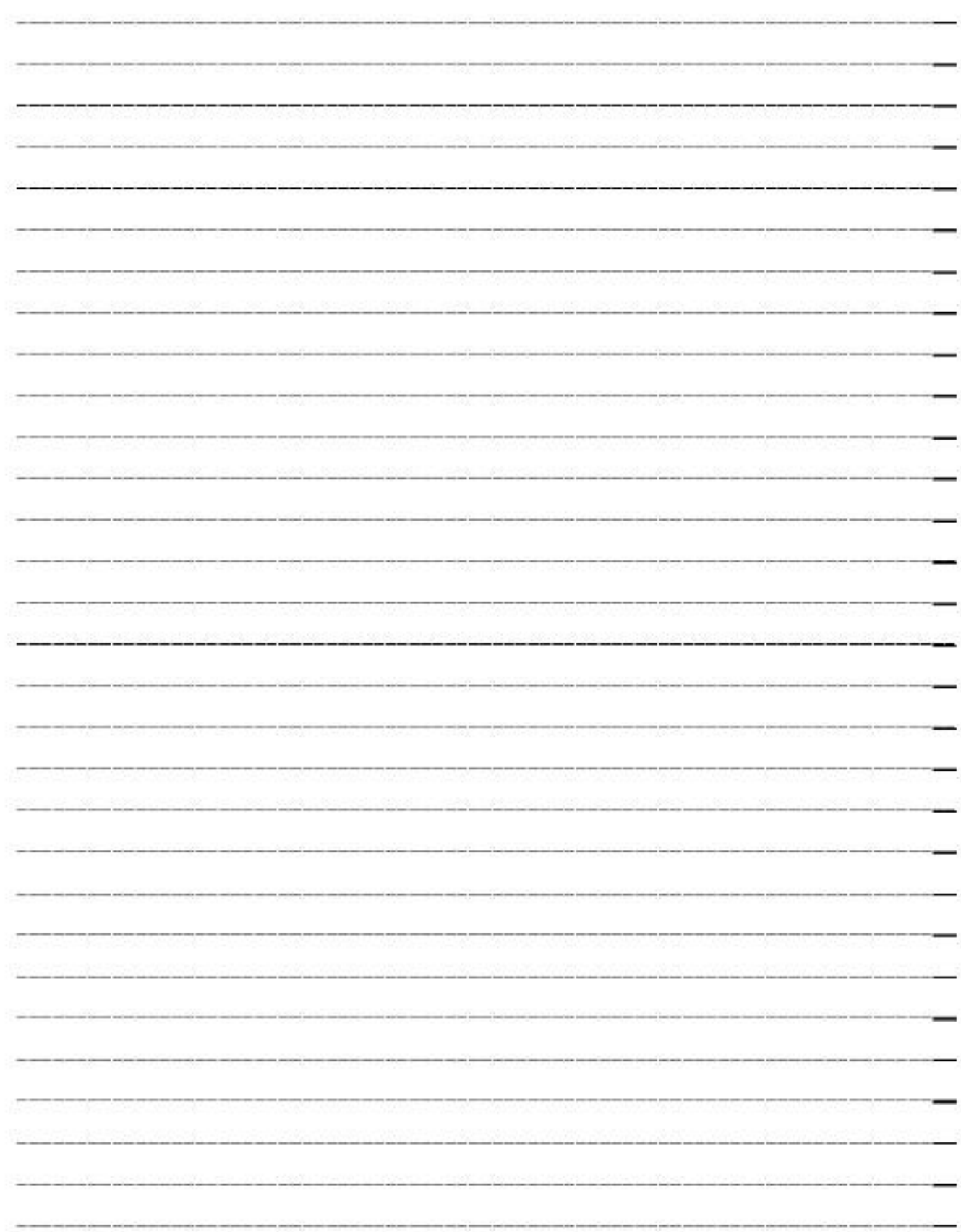




\section{LIST OF REFERENCES}

1. Aizen, I. and Fishbein, M., Understanding Attitudes and Predicting Social Behavior, Prentice Hall Inc., New Jersey, 1980.

2. Armstrong, B. A., "Changing Demographics and the Impact on Air Force Officer Retention," Air Command and Staff College, 2000.

3. Berdie, D. R. and Anderson, J. F., Questionnaires: Design and Use, Scarecrow Press, 1974.

4. Beyers, and et al., "Results of the Nursing Personnel Survey, Vacancies and Turnover," The Journal of Nursing Administration, Vol.13, May 1983.

5. Cary, N. C., Logistic Regression Examples: Using the SAS Systems, SAS Institute Inc., Version 6, First Edition, 1995.

6. Doering, Zahava D. and Grissmer, David W., Active and Reserve Force Attrition and Retention: A Selected Review of Research and Methods, the Rand Corporation, March 1985.

7. Dudley, Robert M. and Hoyle, Richard D., "A Survey of Officer Career Values in the United States Army and the United States Marine Corps and Their Effect on Retention," Master's Thesis, Naval Postgraduate School, Monterey, CA, December 1979.

8. Goode W. and Hatt, P., Methods in Social Research, McGraw Hill, 1962

9. Hayden, Level P., "Factors Influencing the Career Orientation of Junior Officers in The United States Army," Master's Thesis, Naval Postgraduate School, Monterey, CA, March 1985.

10. Johnson, Ian, "Turnover of Junior Army Officers: A Test of the Mobley, Griffeth, Hand and Meglino Model of the Personnel Turnover, Using Structural Equation Techniques," Master's Thesis, Naval Postgraduate School, Monterey, CA, June 1988.

11. Kathryn M. Kocker and George W. Thomas, "Retaining Army Nurses: A Longitudinal Model," Reseach in Nursing \& Health, 1994

12. Lakhani, H., Retention and Cost-Benefit Analysis of Army Junior Officers, Army Institute of Research, 1991.

13. Lempe, Scott J., "A Multivariate Analysis of the Factors Affecting the Retention of First and Second Term Air Force Enlisted Members," Master's Thesis, Naval Postgraduate School, Monterey, CA, December 1989.

14. Lensing, Susan B., "A Model of Career Orientation for Military Nurse Corps Officers," Master's Thesis, Naval Postgraduate School, Monterey, CA, December 1984.

15. Mobley, William H., "Intermediate Linkages in the Relationship between Job Satisfaction and Employee Turnover," Journal of Applied Psychology, Vol. 62, 1977. 
16. Mobley, William H., Horner, Stanley, and Hollingsworth, A. T., "An Evaluation of Precursors of Hospital Employee Turnover," Journal of Applied Psychology, Vol. 63, 1981.

17. Mobley, William H., "Some Unanswered Questions in Turnover Research," Academy of Management Review, Vol. 7, 1982.

18. Moser, C. A. and Kalton, G., Survey Methods in Social Investigation, Heineman Educational Publishing, 1971.

19. Mowday, Richard T., and et al. "Employee-Organization Linkages: The Psychology of Commitment, Absenteeism, and Turnover," Academic Press, 1982.

20. Muchinsky, Paul M. and Turtle, Mark L., "Employee Turnover: An Empirical and Methodological Assessment," Journal of Vocational Behavior, Vol.14, 1980.

21. Muchinsky, Paul M., Psychology Applied to Work, $6^{\text {th }}$ ed., Wadsworth Thompson Learning, 2000.

22. Porter, L., and Steers, R., "Work and Personal Factors in Employee Turnover and Absenteeism," Psychological Bulletin, 1973.

23. Rearden, Anne-Marie, "A Multivariate Analysis of Reenlistment Intentions as A Predictor of Reenlistment Behavior," Master's Thesis, Naval Postgraduate School, Monterey, CA, December 1988.

24. Royle, Marjorie H. and Robertson, David W., "Job Satisfaction Measures As Predictors of Retention for Navy Enlisted Personnel," Naval Personnel Research and Development Center, 1980.

25. Szoc, R. and Seboda, Barbara L., "Follow on Study of Family Factors Critical to Retention of Naval Personnel: The Link between Retention Intention and Retention Behavior," Westinghouse Public Applied Systems Report NR 170-941, 1984.

26. Studenmund, A. H., Using Econometrics: A Practical Guide, Fourth Edition, Adison Wesley Longman, 2001

27. Theilmann, Robert J., "An Analysis of the Factors Affecting Marine Corps Officer Retention," Master's Thesis, Naval Postgraduate School, Monterey, CA, September 1990.

28. Vranken, E. W., The Impact of Deployment Separation on Army Families, Army Institute of Research, 1984.

29. Witzman, R. A., "Estimated Effects of Retirement Revision on Retention of Navy Tactical Pilots," Master's Thesis, Naval Postgraduate School, Monterey, CA, September 1990.

30. Wellington, K.R., “An Analysis of Coast Guard Enlisted," Master's Thesis, Naval Postgraduate School, Monterey, CA, March 1993.

31. Wong L., Generations Apart: Xers and Boomers in the Officer Corps, The Strategic Studies Institute, October 2000.

32. Zinner, Marc A., "U.S Marine Corps Company-Grade Officer Retention," Master's Thesis, Naval Postgraduate School, Monterey, CA, March 1997. 
33. Defense Manpower Data Center, 1978 DoD Survey Officer and Enlisted Personnel User's Manual and Codebook, 1979.

34. Defense Manpower Data Center, 1985 DoD Survey Officer and Enlisted Personnel User's Manual and Codebook, June 1986.

35. Defense Manpower Data Center, 1992 DoD Survey Officer and Enlisted Personnel and Their Spouses User's Manual and Codebook, 1993.

36. Defense Manpower Data Center, 1999 DoD Survey of Active Duty Personnel User's Manual and Codebook, 2000.

37. Office of the Assistant Secretary of Defense, Population Representation in Military Survey FY99, November 2000. 
THIS PAGE INTENTIONALLY LEFT BLANK 


\section{INITIAL DISTRIBUTION LIST}

1. Defense Technical Information Center

Ft. Belvoir, VA

2. Dudley Knox Library

Naval Postgraduate School

Monterey, CA

3. Genel Kurmay Baskanligi Personel Baskanligi

Bakanliklar-ANKARA

TURKEY

4. K.K.K. Personel Baskanligi

Bakanliklar-ANKARA

TURKEY

5. K.K.K. Personel Baskanligi Insan Kaynaklari Dairesi

Bakanliklar-ANKARA

TURKEY

6. Deniz Kuvvetleri Komutanligi Kutuphanesi

06100 Bakanliklar, ANKARA

TURKEY

7. Kara Harp Okulu Kutuphanesi

Bakanliklar, ANKARA

TURKEY

8. Professor George W. Thomas (Code SM/Te)

Naval Postgraduate School

Monterey CA. 93943-5103

9. Kathy Kocher (Code SM/Ko)

Naval Postgraduate School

Monterey CA. 93943-5103

10. Umit Gencer

Uluonder Mah. 6nci Cad.

Ufuk Apt. No 4/7

26190 Tepebasi/Eskisehir TURKEY 